\title{
Copernicus Sentinel-1 MT-InSAR, GNSS and Seismic Monitoring of Deformation Patterns and Trends at the Methana Volcano, Greece
}

\author{
Theodoros Gatsios ${ }^{1,2}$, Francesca Cigna ${ }^{3, *}{ }^{\mathbb{D}}$, Deodato Tapete ${ }^{3}{ }^{\mathbb{C}}$, Vassilis Sakkas ${ }^{1}{ }^{\mathbb{C}}$, \\ Kyriaki Pavlou ${ }^{1}$ (D) and Issaak Parcharidis ${ }^{2}$ \\ 1 Department of Geophysics and Geothermy, National and Kapodistrian University of Athens (NKUA), \\ Panepistimiopolis-Zographou, 15784 Athens, Greece; theogat@geol.uoa.gr (T.G.); vsakkas@geol.uoa.gr (V.S.); \\ kpavlou@geol.uoa.gr (K.P.) \\ 2 Department of Geography, Harokopio University of Athens (HUA), 70 El. Venizelou Str., \\ 17671 Athens, Greece; parchar@hua.gr \\ 3 Italian Space Agency (ASI), Via del Politecnico snc, 00133 Rome, Italy; deodato.tapete@asi.it \\ * Correspondence: francesca.cigna@asi.it
}

Received: 23 August 2020; Accepted: 14 September 2020; Published: 16 September 2020

\begin{abstract}
The Methana volcano in Greece belongs to the western part of the Hellenic Volcanic Arc, where the African and Eurasian tectonic plates converge at a rate of approximately $3 \mathrm{~cm} /$ year. While volcanic hazard in Methana is considered low, the neotectonic basin constituting the Saronic Gulf area is seismically active and there is evidence of local geothermal activity. Monitoring is therefore crucial to characterize any activity at the volcano that could impact the local population. This study aims to detect surface deformation in the whole Methana peninsula based on a long stack of 99 Sentinel-1 C-band Synthetic Aperture Radar (SAR) images in interferometric wide swath mode acquired in March 2015-August 2019. A Multi-Temporal Interferometric SAR (MT-InSAR) processing approach is exploited using the Interferometric Point Target Analysis (IPTA) method, involving the extraction of a network of targets including both Persistent Scatterers (PS) and Distributed Scatterers (DS) to augment the monitoring capability across the varied land cover of the peninsula. Satellite geodetic data from 2006-2019 Global Positioning System (GPS) benchmark surveying are used to calibrate and validate the MT-InSAR results. Deformation monitoring records from permanent Global Navigation Satellite System (GNSS) stations, two of which were installed within the peninsula in 2004 (METH) and 2019 (MTNA), are also exploited for interpretation of the regional deformation scenario. Geological, topographic, and 2006-2019 seismological data enable better understanding of the ground deformation observed. Line-of-sight displacement velocities of the over 4700 PS and 6200 DS within the peninsula are from -18.1 to $+7.5 \mathrm{~mm} /$ year. The MT-InSAR data suggest a complex displacement pattern across the volcano edifice, including local-scale land surface processes. In Methana town, ground stability is found on volcanoclasts and limestone for the majority of the urban area footprint while some deformation is observed in the suburban zones. At the Mavri Petra andesitic dome, time series of the exceptionally dense PS/DS network across blocks of agglomerate and cinder reveal seasonal fluctuation ( $5 \mathrm{~mm}$ amplitude) overlapping the long-term stable trend. Given the steepness of the slopes along the eastern flank of the volcano, displacement patterns may indicate mass movements. The GNSS, seismological and MT-InSAR analyses lead to a first account of deformation processes and their temporal evolution over the last years for Methana, thus providing initial information to feed into the volcano baseline hazard assessment and monitoring system.
\end{abstract}

Keywords: SAR; InSAR; ground deformation; Sentinel-1; volcano monitoring; GNSS; seismicity; ground deformation; slope instability; MT-InSAR 


\section{Introduction}

It is well known that some of the most scenic landscapes and islands of Greece are due to the intense volcanic activity that occurred centuries to millennia ago [1,2]. While Santorini is the most famous and a worldwide renowned touristic site, there are other active volcanic systems (i.e., Milos and Nisyros) within the south Aegean volcanic arc, which were formed from the subduction of the African tectonic plate beneath the Eurasian plate. Of this arc, the Methana peninsula is the westernmost dormant but geodynamically and hydrothermally active volcanic system [3]. The peninsula is connected with the north-eastern coast of Peloponnesus by a narrow gooseneck-shaped isthmus and stretches for approximately $44 \mathrm{~km}^{2}$ northward into the Saronic Gulf.

Of the around 32 andesitic and dacitic lava domes scattered across the peninsula, the Methana volcano is the largest and is the subject of the present study. The volcanic hazard in Methana is considered "low" [4]; given that the last historic eruption was registered in approximately $230 \mathrm{BC}$, volcanic products derived from highly explosive eruptions were not found [3] and no alarming signs were observed in recent times. However, several aspects provide sufficient motivation for a dedicated investigation into the Methana volcano. From a hazard point of view, the neotectonic basin constituting the Saronic Gulf area is considered seismically active [5], and the active fault systems therein were considered preferential paths for present-day geothermal fluid leakage and, as such, potential sites for magma uprising [3]. Thermal springs are indeed clear manifestations of volcanic geothermal energy in Methana, and gas exhalations suggest a mixture between a dominant hydrothermal component and mantle-derived fluids [3]. Additionally, from a risk point of view, the volcano is not far from Athens (less than $50 \mathrm{~km}$ south-west) and any activity at the volcano would impact the local population (about 2500 inhabitants over the year, increasing during summer due to tourism). Further proof that monitoring the Methana volcano has recently been given higher priority on the agenda of Greek institutions is provided by the installations of six seismological stations by the Greek Institute of Geodynamics of the National Observatory of Athens (NOA) [6] alongside a new NOANET Global Navigation Satellite System (GNSS) station [7]. This recent development significantly updates what was stated by [4], i.e., of the whole Greek volcanic arc of Methana-Milos-Santorini (Thera)-Nisyros, Methana is among the volcanic fields not efficiently monitored.

In this context, the present study aims to investigate and characterize the ground motions observed at the surface of Methana volcano based on the results achieved by means of multi-interferogram processing of Synthetic Aperture Radar (SAR) images collected by the Copernicus Programme Sentinel-1 satellite constellation in the period from March 2015 to August 2019. Interferometric SAR (InSAR) approaches have been largely exploited to study and monitor surface deformation at different locations across the volcanic arc (e.g., [8-17]) and have proved their effectiveness to provide a spatially distributed estimation of volcanic activity due to magma chamber processes as well as shallow deformation associated with hydrothermal activity (e.g., low temperature venting). Despite this abundant literature, to the best of our knowledge, no InSAR study has previously focused on Methana.

Given the varied land cover and presence of vegetation at Methana, we intentionally selected a Multi-Temporal InSAR (MT-InSAR) processing approach providing both Persistent Scatterers (PS) and Distributed Scatterers (DS) in order to augment the monitoring capability and the number of measurement points. In this way, we aimed to characterize not only the geodynamics of the whole volcano but also the surface deformation along the steep slopes and stream gullies of the rugged terrain of the volcanic landforms, of which the susceptibility to landslides and rockfalls has been already highlighted in the literature [18]. Satellite MT-InSAR is complemented and interpreted in combination with an analysis of regional seismicity characterizing the 2006-2019 period and with geodetic data from continuous GNSS monitoring and Global Positioning System (GPS) benchmark surveying. The latter is also used to calibrate and validate the MT-InSAR results, thus tying the satellite-based estimates to the local geodetic reference used in the region and providing evidence to corroborate MT-InSAR observations. 


\section{The Study Area}

Methana peninsula is located in the western Saronic Gulf south of Athens city (Figure 1) and is one of the three volcanic centres (i.e., Aegina, Poros and Methana) representing the north-western part of the active volcanic arc of the South Aegean. This Hellenic active volcanic arc also includes the islands Milos, Santorini and Nisyros in its extension [19]. Methana and the other volcanic centres in the Saronic Gulf are mostly monogenetic, and no composite volcanic structures are present [20].

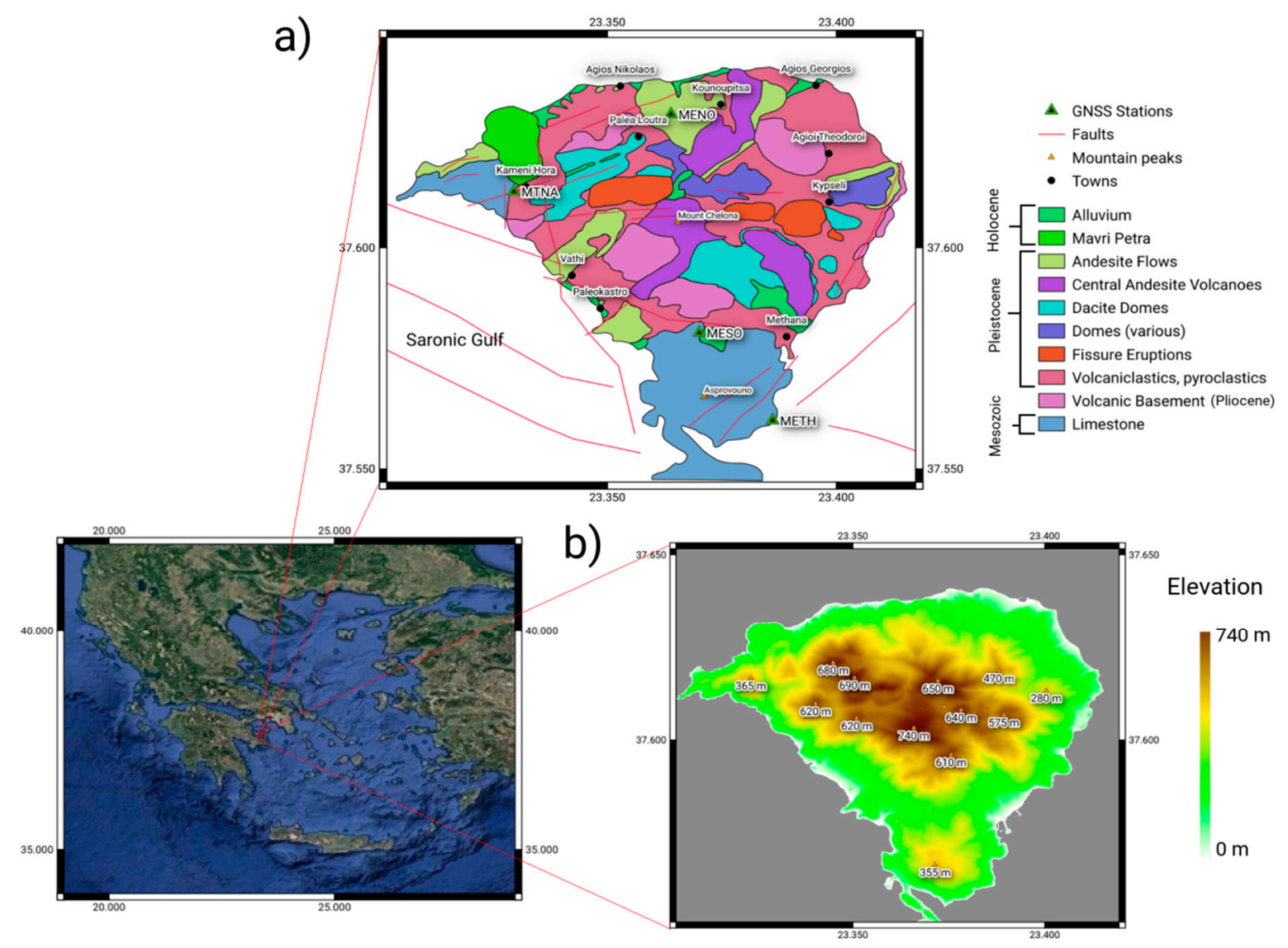

Figure 1. (a) Simplified geological map of the Methana peninsula, Greece (modified after [21-23]), with indication of Global Navigation Satellite System (GNSS) stations and local benchmarks and (b) topography from a 5.5-m resolution digital surface model by the Hellenic Mapping and Cadastral Organisation.

According to [24], the Saronic Gulf is the longest active area of the South Aegean with geothermal springs which are influenced by the active tectonic structure of the area as well as the existence of the magmatic chamber. Volcanic activity in Methana lasted until 1700, when a submarine eruption occurred north of Kameni Chora. Present day, active geothermal springs are reported mainly in the eastern and northern parts of the peninsula [3]. Within Methana town, in the south-east, the thermal springs are exploited at the open-air baths of the Thermal Spa and its neoclassical dwelling built in 1930.

It is also crucial to mention the presence of the Pausanias submarine volcano, located $2 \mathrm{~km}$ off the north-western shore of the peninsula [25]. According to [26], this submarine volcano was discovered using seismic reflection data and volcanic activity occurred during the 3rd century BC.

The Saronic Gulf constitutes a neotectonic basin which was created $4-5$ million years ago $[27,28]$. NE-SW normal faults dominate the broader region, while N-S, E-W and NNE-SSW striking normal faults are also recognizable in the area [25] and are characterized by low seismic activity, chiefly with shallow events [29]. 
The geology of Methana consists of various volcanic formations with Late Pliocene-Pleistocene small andesitic to dacitic flows and domes [30,31], which overlay the older volcanic rocks, as well as the Mesozoic sedimentary basement [21,32].

A simplified geological map (Figure 1a) shows that the grey limestones are present in the northwest (Upper Triassic-Lower Jurassic), while limestones with dolomites are present in the south (Upper Jurassic-Cretaceous). These limestones constitute the basement of Methana and are located under the volcanoclastic formations (rhyolite, dacite and andesite) [33]. Additionally, the Methana peninsula has many tectonic faults, with a major fault crossing the town of Methana from west to east.

The tectonic regime of the region combined with the volcanic activity determined a rough topography of the peninsula, which shows both flat basin areas with Quaternary fill and zones dominated by high slope gradients and narrow valleys, often modelled by erosion processes (such as in the south, between Vathi and Methana) [18]. The maximum elevation is $740 \mathrm{~m}$ above sea level (a.s.l.) and occurs at Helona Mountain (Figure 1b).

\section{Materials and Methods}

\subsection{SAR Data and Multi-Temporal InSAR Processing}

A long stack of 99 SAR scenes acquired by the Copernicus Sentinel-1A and Sentinel-1B satellites in ascending mode (relative orbit 102) was used in this study. SAR images are remote sensing satellite data increasingly used for observing, mapping and monitoring Earth's surface processes [34] and are characterized by cloud-penetrating, day and night operational capabilities.

Among the Sentinel-1 SAR constellation imaging modes, we used the Interferometric Wide (IW) swath, which is based on the novel Terrain Observation with Progressive Scans (TOPS) strategy [35]. IW images are composed of three sub-swaths (i.e., IW1, IW2 and IW3), each consisting of a series of bursts, and provide a 250-km large coverage, with pixel resolutions of $5 \mathrm{~m}$ and $20 \mathrm{~m}$ (single look) in range and azimuth, respectively [36]. The Sentinel-1 data used in this study were collected from the Sentinel Hub platform and cover the time period from March 2015 to August 2019. The ascending mode acquisition geometry was selected to undertake the analysis in order to optimize visibility of the east-facing slopes, where the town of Methana (and thus the major urban settlement of the peninsula) is located (see Figure 1).

The stack of 99 Sentinel-1 SAR scenes was processed using an advanced MT-InSAR approach, an extension of the basic technique of Differential InSAR (DInSAR; e.g., [37,38]), that is based on the phase comparison of multiple SAR images gathered at different times over the study region and allows for measurements of land deformation along the line-of-sight (LOS) direction of the SAR sensor with up to millimetre precision (e.g., [39]). Advanced DInSAR methods are increasingly being used in various applications in the field of volcanology, seismology, crustal dynamics, landslides, land subsidence and geothermal energy exploitation (e.g., [40-45]).

MT-InSAR methods exploit either Persistent (PS) or Distributed (DS) Scatterers or coherent targets. Typically, PS are artificial objects that reflect the radar signal well, such as metal structures, buildings and rock outcrops, and are used in Persistent Scatterer Interferometry (PSI), e.g., the Permanent Scatterers (PS-InSAR) technique [46,47]. In urban areas, there is a prevalence of PS, and PSI methods allow for analysis of even individual structures on the ground. Methods exploiting coherent targets include algorithms such as the Small BAseline Subset (SBAS) method [48]. DS reflects lower radar energy compared to PS targets and usually spans several pixels in high-resolution SAR images [49], which exhibit similar scattering properties and can be used together for deformation estimation. The identification and monitoring of such targets is helpful especially in suburban and more rural areas, where the density of PS can be low. In such circumstances, the combination of PS and DS is important for effective displacement monitoring using SAR Single Look Complex (SLC) data. What is certain is that the processing aiming to detect both PS and DS requires large computing resource and processing time [50]. 
Concerning the precision of MT-InSAR measurements, error bars are extremely complex to estimate theoretically, since they depend on several factors, including the number of SAR SLC images used, the spatial density and quality (signal-to-noise ratio levels) of the measurement targets, their distance from the reference PS, the climatic conditions at the time of SAR acquisition and the satellite repeat cycle. Recent studies provide an empirical relationship between the number of SAR interferograms used and the resulting precision of the ground deformation estimates (e.g., by using 50 ERS-1/2 interferograms, a precision of $0.15 \mathrm{~cm} /$ year can be achieved with the SBAS method [51]).

In this study, the GAMMA SAR and Interferometry software (GAMMA Remote Sensing AG, Gümligen, Switzerland) and the Interferometric Point Target Analysis (IPTA) method [52] were used for the interferometric processing. The MT-InSAR processing workflow can be divided into two steps: the pre-processing and the main processing using GAMMA/IPTA.

During pre-processing, parameter files for the 99 SLC images were created and used to perform orbital refinement. The SLC images were co-registered based on the image used as a reference (20/09/2017), and a single-reference stack of 98 differential interferograms was generated. The Shuttle Radar Topography Mission (SRTM) 1-arcsec (i.e., $30 \mathrm{~m} /$ pixel) Digital Elevation Model (DEM) [53] was used during pre-processing to subtract the topography contribution from the interferograms.

Using the 99 co-registered SLC images, a multi-reference stack was also created, containing both single-pixel and multi-look differential interferometric phases. Multi-look differential interferometric phases (DS) were first generated, and afterwards, single-pixel differential interferometric phases (PS) were estimated using low spectral diversity and temporal variability of SLC intensity. Then, single-look and multi-look phases were combined into one list of both PS and DS. The multi-reference stack consists of 291 differential interferograms, pairing each scene with the 3 subsequent scenes (triple redundancy). The perpendicular baselines of those 291 pairs were quite short, with the longest baseline being $202 \mathrm{~m}$. A high-accuracy Digital Surface Model (DSM) $(5.5 \mathrm{~m} / \mathrm{pixel})$ provided by the Hellenic Mapping and Cadastral Organisation (Figure 1b) was also used for the IPTA in order to improve the quality of the output results. As reference point, the closest point to the GPS benchmark “Methana South" (i.e., MESO station in Figure 1a; $37^{\circ} 34^{\prime} 51.02562^{\prime \prime}$ N, $23^{\circ} 22^{\prime} 12.14638^{\prime \prime}$ E) was selected. Then, height corrections and atmospheric phases were computed using the combined point list.

The above model was refined by updating height corrections and atmospheric phases via iteration of the last step two more times. Finally, the phases were converted into deformation time series, which contained both PS and DS. Then, the deformation time series database was split into two separate ones, one for the PS and the other for the DS targets.

\subsection{GNSS Continuous Monitoring Data and GPS Benchmark Surveying}

A small network of two benchmark stations was established in 2006 in Methana Peninsula (Figure 1) [54]. These two stations were part of a larger GPS network established in the north-western part of the Hellenic Volcanic Arc (including the island of Aegina and the volcanic area of Susaki) aiming to study the ground deformation of this area. The stations in Methana were located in the northern (i.e., station MENO) and southern (MESO) parts of the peninsula and were reoccupied several times up to December 2019. All measurements took place approximately within the same period of the year (usually late October to December) in an effort to minimize seasonal phenomena. The Methana benchmark network was occupied using Leica receivers (SR9500 and AX1200). For each measurement period, the two benchmark stations were occupied for a period of 48 to $60 \mathrm{~h}$, with time sampling of $15 \mathrm{~s}$. Such time sampling was used for local-scale solutions with nearby continuous GNSS stations for which data were available with the same time sampling. While on regional-scale solutions, the data were resampled to 30-s data sets in order to be processed together with the freely distributed 30-s GNSS data available for European stations.

In early 2015, a continuous GNSS (cGNSS) station was also established in the Lygourio (LYGO) close to Methana peninsula as part of the HxGN SmartNet (https://gr.nrtk.eu/), that, ever since, has acted as local reference station. In addition, since August 2019, cGNSS data were available from 
a station (MTNA) located in the western part of Methana peninsula as part of the GNSS network of the Institute of Geodynamics, National Observatory of Athens (NOA). Horizontal velocity results from two more cGNSS stations were also available from the National Technical University of Athens (NTUA), i.e., station METH installed in 2004 in the southern sector of Methana peninsula, and from [55], i.e., station 010A located to the south-east of Methana peninsula, at Poros.

The available 30-s data from the two cGNSS stations (i.e., LYGO and MTNA) that were included in this study were processed separately on a daily basis together with several other cGNSS stations located in Greece as part of a regional network. From the time series of the station's coordinates, the cGNSS station velocity was estimated in the IGb08 reference frame (see Figures A1 and A2 in Appendix A).

The GPS data were processed using BERNESE software (v.5.2, University of Bern, Bern, Switzerland) [56]. The software allows for the estimation of epoch-wise receiver coordinates in Precise Point Positioning (PPP) mode as well as in the double difference mode. For the present research, the coordinates were calculated on a static mode. To get the best results, the PPP technique was used as a first step to get a priori coordinate values that were consequently introduced in the more precise double difference method. The GPS data from the benchmark stations and the other cGNSS stations in the broader area of Methana were processed together with several other EUropean REference Frame (EUREF) and cGNSS stations from Europe and Greece (http://www.epncb.oma.be) in order to define the local reference frame and to calculate the station coordinates. All measurement periods were processed with respect to the IGb08 reference frame (http://igscb.jpl.nasa.gov/network/refframe.html). Absolute antenna phase centre corrections were used in the data analysis. Several supporting files were introduced during the processing steps, aiming to define precise coordinates for the stations. Precise orbits from CODE analysis centre (ftp://ftp.unibe.ch/aiub/CODE) were used in the analysis, and a set of Earth orientation parameters was calculated. Crustal deformation caused by changing mass due to ocean tides and the atmosphere was taken into consideration, introducing auxiliary files. For the ocean loading effect, tide loading corrections were based on the FES2004 model (http://holt.oso.chalmers.se/loading). Atmospheric tidal loading coefficients were used from a global grid based on the Ray and Ponte (2003) model [57]. For troposphere modelling, the Vienna Mapping Function (http://ggosatm.hg.tuwien.ac.at) as well as the Neill mapping function were used. Ambiguities were solved using several resolution strategies based on the baseline length and the occupation time: (i) the wide-lane and narrow-lane techniques for the medium baselines $(<10-200 \mathrm{~km})$, where initially the L5 linear combination is processed (wide-lane) and introduced as known (fixed) in the subsequent run (narrow-lane) where the L3 linear combination is processed; (ii) the SIGMA strategy for the very short baselines (in between the two Methana stations, where both L1 and L2 data were available and used); and finally, (iii) the quasi-ionosphere-free (QIF) strategy for the long baselines $(<1000-2000 \mathrm{~km})$ were the main adopted ambiguity resolution strategies.

The long occupational time of the two GPS benchmark stations in Methana, during all measurement periods, resulted into low uncertainties (at a 95\% confidence level) with overall errors of about 2.4-3.1 $\mathrm{mm}$ and $2.5-5.1 \mathrm{~mm}$ for the horizontal and vertical coordinates, respectively. The processing performed on daily sessions allowed for the extraction of a set of coordinates for each 24-h long period. The final set of coordinates was the mean value of all the sessions, and the errors led to quantification of the deviation of the daily coordinate solutions from the mean value.

\subsection{Seismological Data and Processing}

The digital seismological data used in this study were obtained from the database of the seismological laboratory of the National and Kapodistrian University of Athens (NKUA; http://dggsl. geol.uoa.gr/en_index.html).

The optimization of epicentres for the period 2006-2019 was carried out using the HYPOINVERSE software (v.1.4, United States Geological Survey: Menlo Park, CA, USA) [58]. The final quality of the relocated epicentres is very satisfactory due to the use of the one-dimension local velocity model 
developed by Karakonstantis et al. [59]. In particular, the root mean square (RMS) travel-time residual for the whole study period was determined to be $0.46 \mathrm{~s}$, while the means of the horizontal and vertical direction uncertainties for the events' hypocentres are $1.51 \mathrm{~km}$ and $5.82 \mathrm{~km}$, respectively.

The seismological data were divided into two time periods. The first one coincided with the time period that the GNSS data cover, i.e., January 2006 to August 2019, while the second period covered the time span of the interferometric processing, i.e., March 2015 to August 2019 (see Section 3.1).

\section{Results and Discussion}

\subsection{Evidence from the GNSS Data Analysis}

The observed velocities (i.e., $V_{E}, V_{N}$ and $V_{U}$, along the east-west, north-south and vertical direction, respectively) and associated standard deviations (i.e., STDV) from all cGNSS and local benchmark stations are presented in Table 1. The LYGO cGNSS station exhibited SSE motion (Figure 2), calculated for a period of more than five years, that describes the anticipated regional motion of the area with respect to IGb08 [55] and is in good agreement with the two other cGNSS stations: METH and 010A. The newly established cGNSS station in the western Methana peninsula (i.e., MTNA) showed significantly different velocity due to the short period that the station was operating (i.e., from August to December 2019). The limited operational period reveals only a short portion of the station's annual trend and therefore could be biased by interannual variations. Consequently, these data have been excluded from further investigation but still briefly presented for future comparison (see Figure A1 in Appendix A). The velocity results from the two local benchmark stations in Methana peninsula (i.e., MENO and MESO) for a period of almost fourteen years (2006-2019) appeared consistent with the regional velocity field concerning the horizontal component (Figure 2). However, the southern station (i.e., MESO) revealed significant subsidence that has to be correlated with the MT-InSAR results (see Section 4.5).

Table 1. Velocity values of the continuous Global Navigation Satellite System (cGNSS) and local Global Positioning System (GPS) benchmark stations in Methana peninsula and the broader area in the IGb08 reference frame. Notation: $V$, velocity; $S T D V$, standard deviation; E, east-west; N, north-south; and $\mathrm{U}$, vertical/up.

\begin{tabular}{|c|c|c|c|c|c|c|}
\hline Station & $\begin{array}{c}V_{E} \\
\text { (mm/year) }\end{array}$ & $\begin{array}{c}V_{N} \\
\text { (mm/year) }\end{array}$ & $\begin{array}{c}V_{U} \\
\text { (mm/year) }\end{array}$ & $\begin{array}{c}S T D V_{E} \\
\text { (mm/year) }\end{array}$ & $\begin{array}{c}S T D V_{N} \\
\text { (mm/year) }\end{array}$ & $\begin{array}{c}S T D V_{U} \\
\text { (mm/year) }\end{array}$ \\
\hline LYGO & 6.99 & -12.97 & -0.76 & 0.05 & 0.07 & 0.08 \\
\hline MTNA & 7.02 & 3.35 & 4.88 & 1.26 & 1.76 & 6.37 \\
\hline MENO & 6.50 & -12.89 & -0.21 & 0.21 & 0.33 & 0.30 \\
\hline MESO & 7.02 & -12.77 & -5.24 & 0.15 & 0.08 & 1.12 \\
\hline METH * & 6.77 & -12.51 & - & 0.45 & 0.44 & - \\
\hline 010A* & 7.41 & -13.01 & - & 0.43 & 0.44 & - \\
\hline
\end{tabular}

Aiming to better define the local deformation in Methana peninsula, the regional velocity vector (as it was estimated in LYGO cGNSS station) was subtracted from the two local GPS benchmark stations as well as the two other cGNSS sites (i.e., METH and 010A). Although the resulting horizontal velocity vectors are very small $(<1 \mathrm{~mm} /$ year) with significant errors (Table 2$)$ indicating a uniform deformation of the broader Methana area, there is a pattern of differential motion in the area (Figure 3). The northern station (i.e., MENO) exhibits a westward motion, while the southern sites (i.e., MESO and METH) showed a northward motion. However, the latter is quite arbitrary due to the small horizontal velocity values and the resulting errors. The more evident differential behaviour between these two stations is in the vertical component (Table 2), with the southern station (i.e., MESO) exhibiting noticeable subsidence, as it was mentioned previously. 


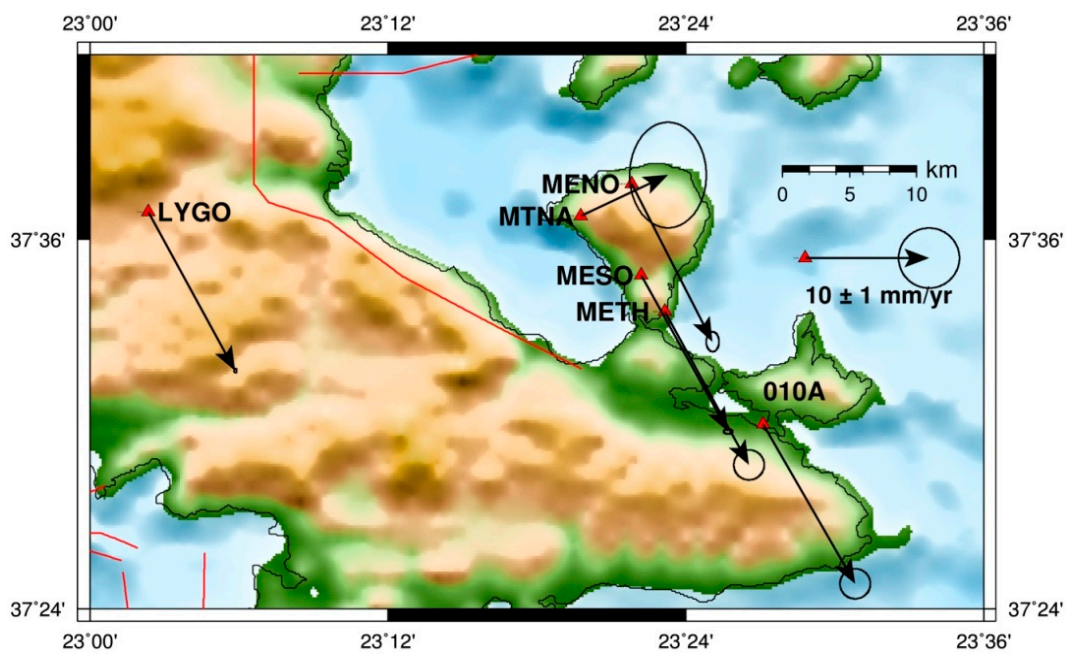

Figure 2. Horizontal velocity vectors from cGNSS and local GPS benchmark stations in the broader area of Methana peninsula with respect to the IGb08 reference frame. Stations METH and 010A were retrieved from other sources (NTUA and [55]).

Table 2. Local velocity values of the benchmark stations in Methana Peninsula with respect to LYGO station. Notation: $V$, velocity; $S T D V$, standard deviation; E, east-west; $\mathrm{N}$, north-south; and U, vertical/up.

\begin{tabular}{ccccccc}
\hline Station & $\begin{array}{c}V_{E} \\
(\mathbf{m m} / \text { year })\end{array}$ & $\begin{array}{c}V_{N} \\
(\mathbf{m m} / \text { year })\end{array}$ & $\begin{array}{c}V_{U} \\
(\mathbf{m m} / \text { year })\end{array}$ & $\begin{array}{c}S T D V_{E} \\
(\mathbf{m m} / \text { year })\end{array}$ & $\begin{array}{c}S T D V_{N} \\
(\mathbf{m m} / \text { year })\end{array}$ & $\begin{array}{c}S T D V_{U} \\
(\mathbf{m m} / \text { year })\end{array}$ \\
\hline LYGO & - & - & - & & & \\
MENO & -0.49 & 0.08 & 0.55 & 0.216 & 0.337 & 0.311 \\
MESO & 0.03 & 0.2 & -4.48 & 0.158 & 0.106 & 1.123 \\
METH $^{*}$ & -0.22 & 0.46 & - & 0.453 & 0.435 & \\
$010 A^{*}$ & 0.42 & -0.04 & - & 0.433 & 0.445 & \\
\hline
\end{tabular}

* Values provided by NTUA and [55].

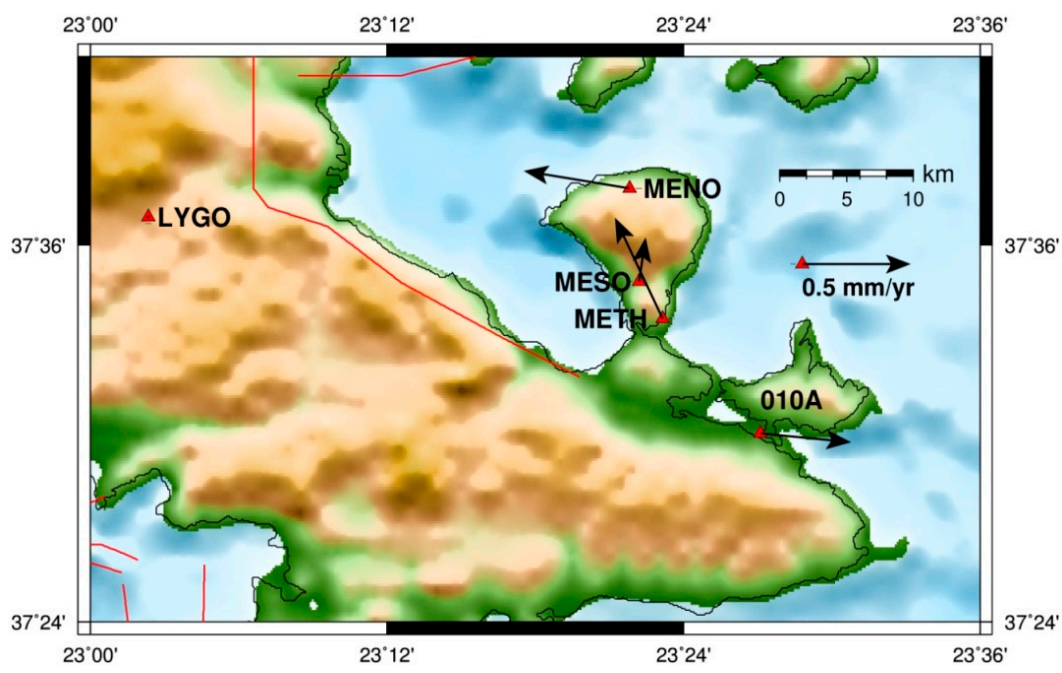

Figure 3. Local horizontal velocity field calculated with respect to the LYGO cGNSS site.

\subsection{Observations from the Seismic Data Analysis}

The analysis of the seismic data shows that the Saronikos Gulf region is mainly characterized by moderate seismic events and shallow depths, as already discussed in the literature [29]. During the period from 2006 to February 2015, the most important earthquakes occurred in 2008, 2012 and 2014, with magnitudes $(\mathrm{Mw})$ of 3.4 to 4.2 and focal depths of 8 to $16 \mathrm{~km}$. The focal mechanism solutions 
indicate the activation of NW-SE or NE-SW striking normal faults (Figure 4). Two clusters of intense seismic activity are located offshore: between Methana and Poros Island, and NE of Aegina Island. Shallow microseismicity is observed NW of Saronikos Gulf (in an area where the 2012 and Mw 4.1 earthquake occurred), offshore NW of Aegina island and at the southern coast of Attica (Figure 4).

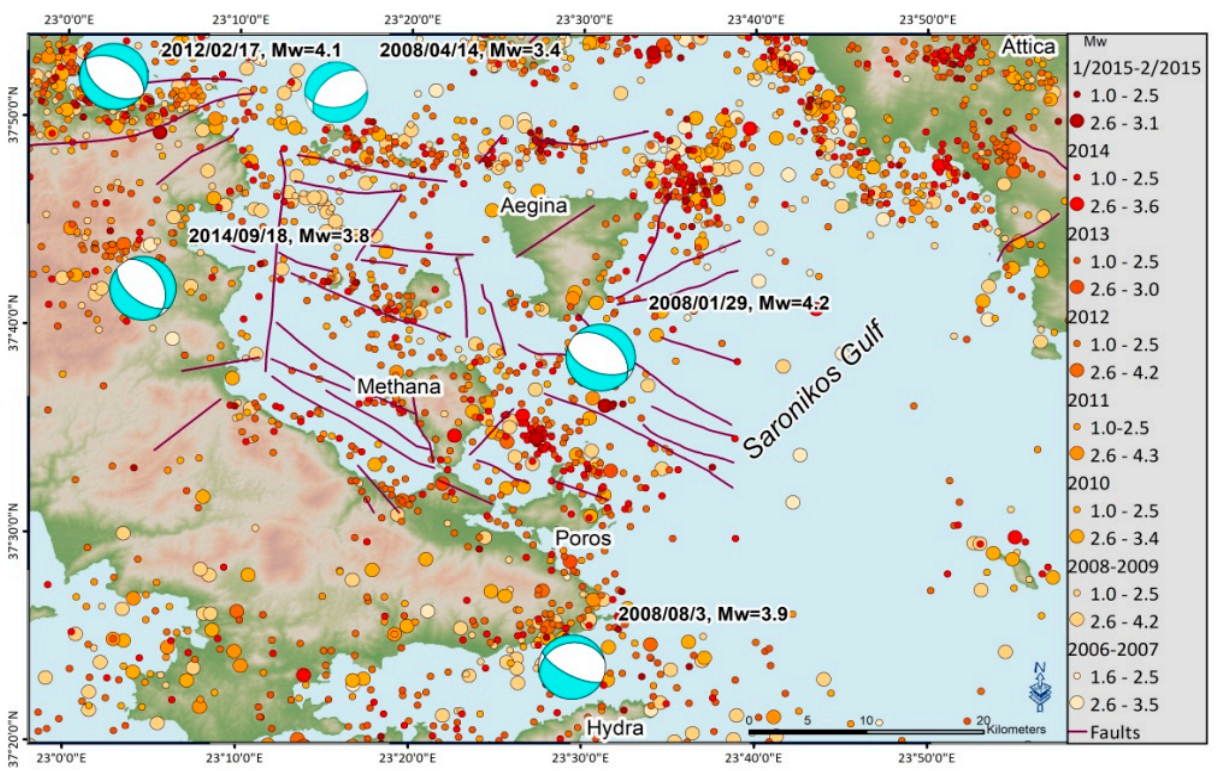

Figure 4. Seismic activity recorded in 2006-February 2015.

For the period 2015-2019, there were three significant seismic events in the area: two moderate shallow earthquakes with magnitudes $\mathrm{Mw}=3.8$ and $\mathrm{Mw}=3.6$ and a very deep one (depth $=142 \mathrm{~km}$ ) with magnitude $\mathrm{Mw}=4.2$ (Figure 5). In this period, a significant seismic swarm was observed NE of Poros Island. The seismic activity in this cluster started in 2016 and continued with few events up to 2019. Additional to the surface seismicity, very deep (80-100 km) sporadic micro-events took place on a wider area extending from Methana towards Hydra Island. These deep micro-events may be attributed to the NE-subduction zone of the Ionian oceanic plate that reaches very deep in this area $[5,54,59,60]$.

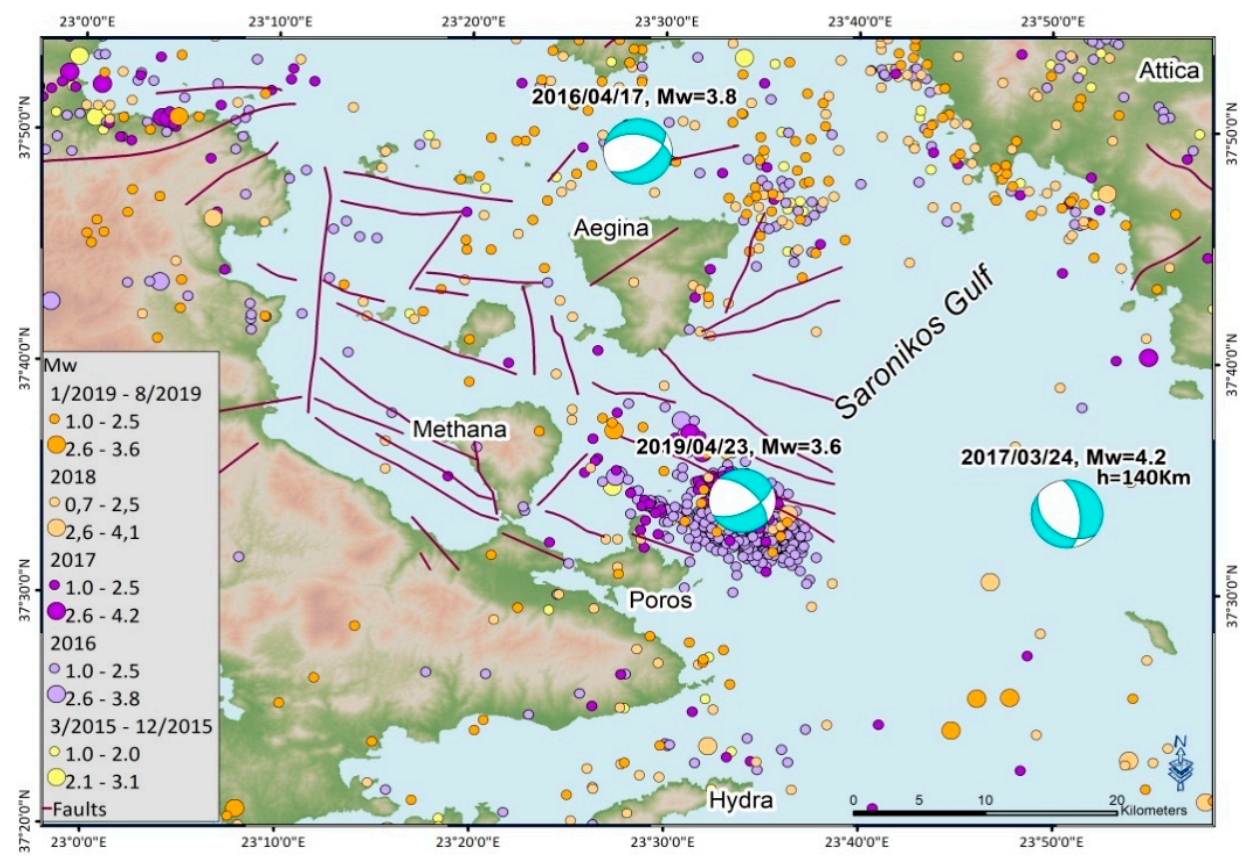

Figure 5. Seismic activity recorded in March 2015-August 2019. 


\subsection{PS and DS Distribution}

After MT-InSAR processing, 4769 PS targets and 6234 DS targets were retrieved (Figure 6). The spatial densities of the targets in the area were calculated as $95.14 \mathrm{PS} / \mathrm{km}^{2}$ and $124.36 \mathrm{DS} / \mathrm{km}^{2}$ by considering the whole landmass of the peninsula (approximately $50 \mathrm{~km}^{2}$ ). Most of the targets are located at low altitudes (up to approximately 100-150 $\mathrm{m}$ a.s.l. for PS and up to approximately 350-400 m a.s.1. for DS), where there are urban settlements, and also on geological formations which exhibit high coherence, such as volcanoclasts. PS targets have a coherence greater than 0.70 , while the DS have coherence greater than 0.79 .

a)
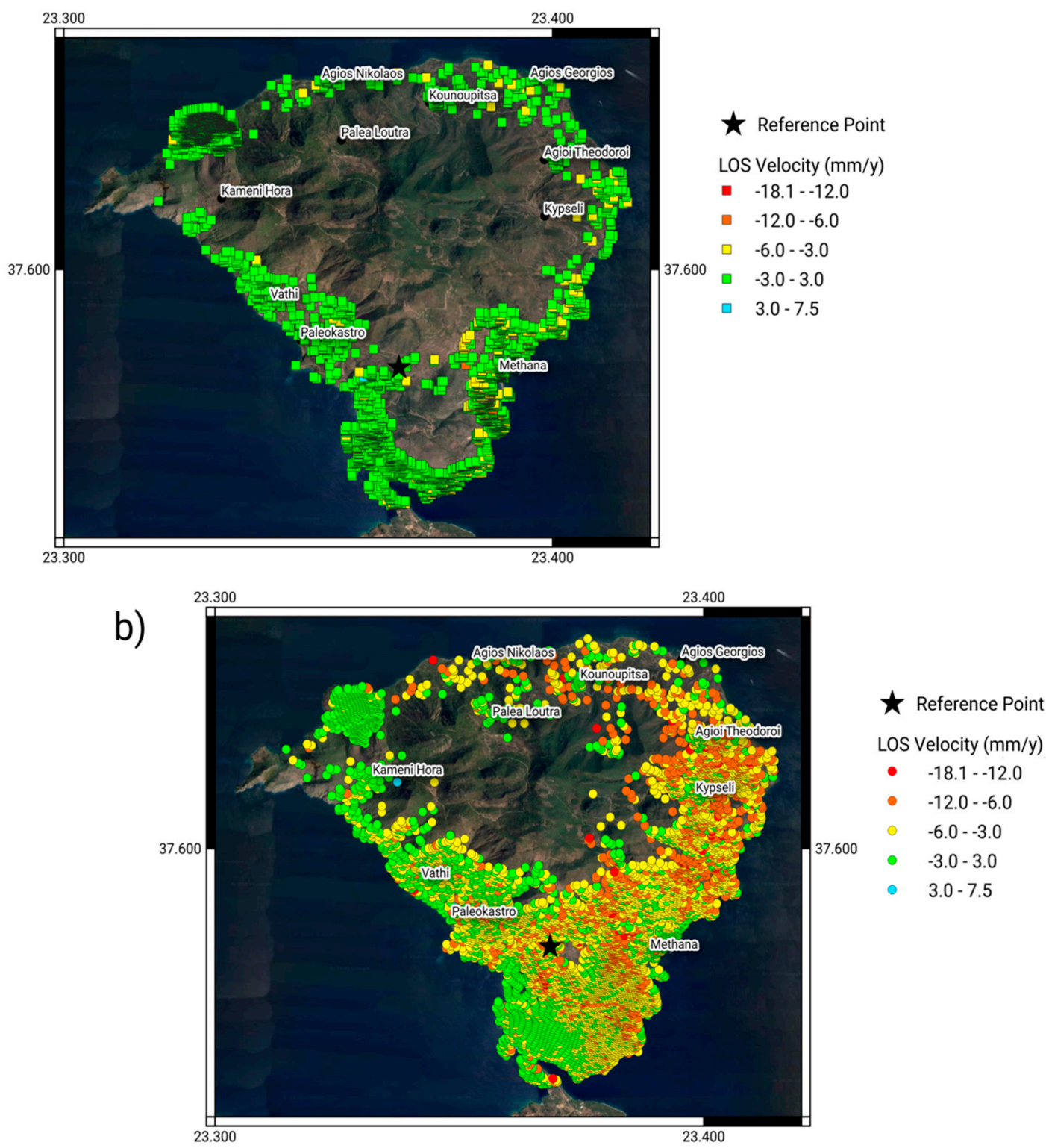

Figure 6. Line-of-sight (LOS) deformation velocity in 2015-2019 from the Multi-Temporal Interferometric Synthetic Aperture Radar (MT-InSAR) analysis for the (a) Persistent Scatterers (PS) and (b) Distributed Scatterers (DS) datasets, overlapped onto satellite optical imagery (C) 2020 TerraMetrics, (C 2020 Google).

Very dense coverage of PS is observed at the Mavri Petra andesitic dome north of Kameni Chora village due to the strong coherence over areas with sparse vegetation and bare ground, in particular over large blocks of agglomerate and cinder (Figure 7). The Mavri Petra unit has the greatest density of PS with $1241 \mathrm{PS} / \mathrm{km}^{2}$ and a density of DS of $198 \mathrm{DS} / \mathrm{km}^{2}$. The density of PS on Mavri Petra is even greater than in Methana town, which is an urban area (see Section 4.5). Methana town has 794 PS/km² 
and $479 \mathrm{DS} / \mathrm{km}^{2}$. The lowest density of PS was observed in alluvial areas due to much lower coherence, with $156 \mathrm{PS} / \mathrm{km}^{2}$ and $195 \mathrm{DS} / \mathrm{km}^{2}$. Volcanoclastic units have densities of $397 \mathrm{PS} / \mathrm{km}^{2}$ and $784 \mathrm{DS} / \mathrm{km}^{2}$.
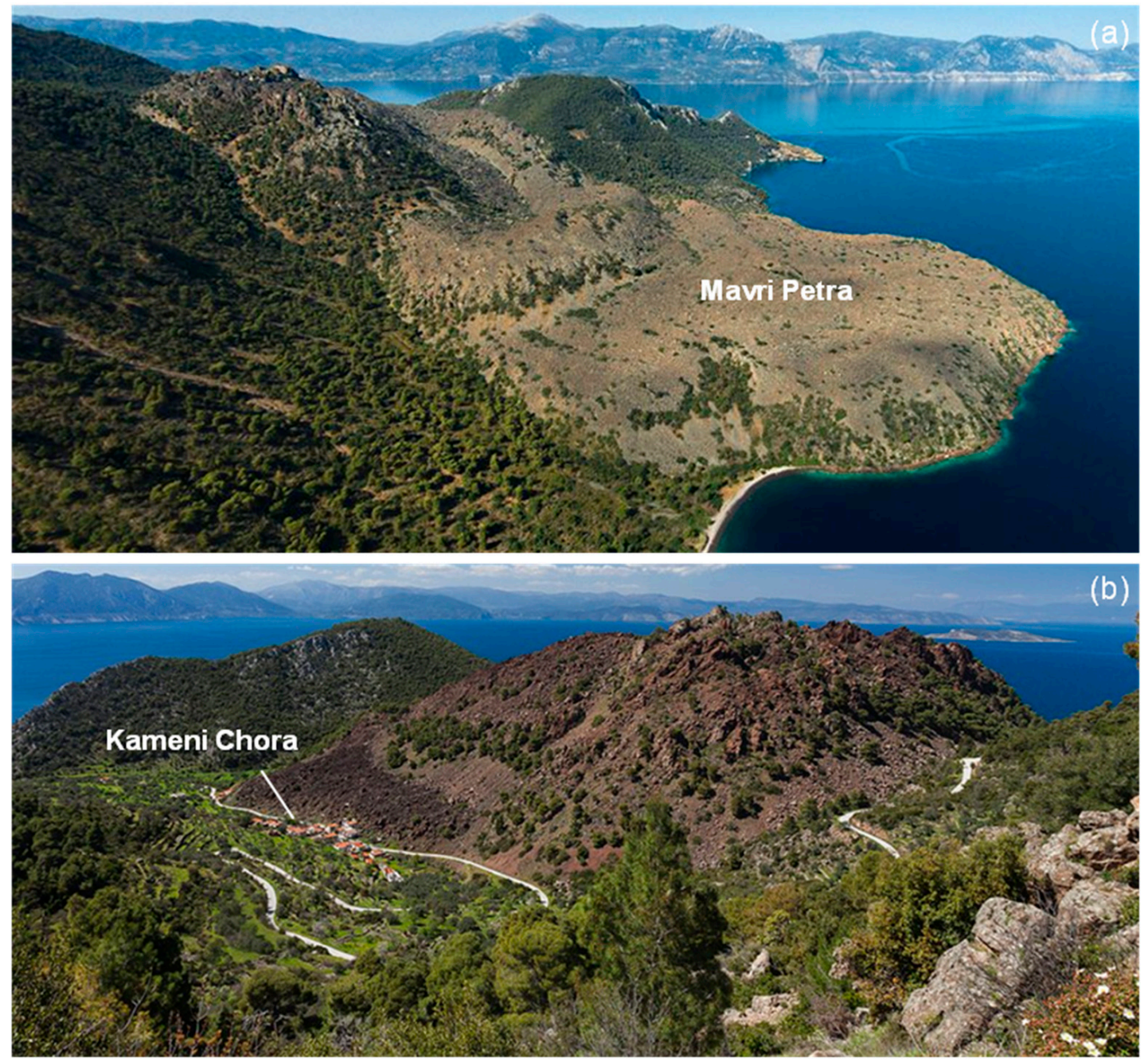

Figure 7. (a) Aerial view of the Mavri Petra andesitic dome and (b) details from the south-east, including Kameni Chora village (photographs (C) TobiasSchorr@Methana.de).

\subsection{MT-InSAR Data Precision, Calibration and Validation}

The present study is based on ascending SAR dataset only (see Section 3.1). Therefore, all results and values reported hereinafter are LOS values if not explicitly stated otherwise.

The uncertainty observed in the estimated $V_{\text {LOS }}$ (i.e., standard deviation of the time series) is $2.8 \mathrm{~mm} /$ year on average for the PS dataset and $2.6 \mathrm{~mm} /$ year for the DS dataset. These values provide an indication of the precision of the MT-InSAR results and suggest that the $\pm 3.0 \mathrm{~mm} /$ year $V_{\text {LOS }}$ interval can be considered the velocity range, indicating stability.

On the other hand, in order to estimate the accuracy of the MT-InSAR results, these were validated using the local velocity values of the GPS benchmark stations MESO and MENO in Methana Peninsula with respect to LYGO cGNSS station (Table 2). A frame of reference transformation was applied to the velocity vectors in order to calculate the estimated LOS velocity of the two GPS benchmark stations and to allow for comparison with the MT-InSAR data. 
Knowledge of the Euler angles (i.e., $\omega_{x}, \omega_{y}$ and $\omega_{z}$; Table 3) of the Sentinel-1 LOS along the ascending relative orbit 102 allowed us to generate the rotation table for each axis: $R_{1}, R_{2}$ and $R_{3}$ via Equations (1)-(3), respectively:

$$
\begin{aligned}
& R_{1}=\left[\begin{array}{ccc}
1 & 0 & 0 \\
0 & \cos \omega_{x} & \sin \omega_{x} \\
0 & -\sin \omega_{x} & \cos \omega_{x}
\end{array}\right] \\
& R_{2}=\left[\begin{array}{ccc}
\cos \omega_{y} & 0 & -\sin \omega_{y} \\
0 & 1 & 0 \\
\sin \omega_{y} & 0 & \cos \omega_{y}
\end{array}\right] \\
& R_{3}=\left[\begin{array}{ccc}
\cos \omega_{z} & \sin \omega_{z} & 0 \\
-\sin \omega_{z} & \cos \omega_{z} & 0 \\
0 & 0 & 1
\end{array}\right]
\end{aligned}
$$

Table 3. Euler angles of the Sentinel-1 LOS along ascending mode relative orbit 102.

\begin{tabular}{ccc}
\hline Euler Angle & Degrees & Physical Interpretation \\
\hline$\omega_{x}$ & 0 & - \\
$\omega_{y}$ & -37.1 & Incidence angle \\
$\omega_{z}$ & 11 & Declination from the north (azimuth) \\
\hline
\end{tabular}

The right-hand rule was used to calculate the Euler angles because the reference frames are right-handed. The incidence angle for the area where the two GPS benchmark stations are found (namely, $\omega_{y}$ ) was estimated using the European Space Agency (ESA)'s SeNtinel Application Platform (SNAP) software - Sentinel-1 toolbox S1TBX (v.7.0, SkyWatch, Waterloo, Canada), while the azimuth angle of the ascending relative orbit 102 in the area (namely, $\omega_{z}$ ) was estimated using QGIS software (v.3.14, QGIS.ORG, Switzerland).

Then, using Equation (4), the rotation matrix (5) was composed and finally exploited to transform the reference frame into the LOS geometry:

$$
\begin{gathered}
R=R_{1}\left(\omega_{x}\right) \cdot R_{2}\left(\omega_{y}\right) \cdot R_{3}\left(\omega_{z}\right) \\
R=\left[\begin{array}{ccc}
0.78293 & 0.15219 & 0.60321 \\
-0.19081 & 0.98163 & 0 \\
-0.59213 & -0.11510 & 0.79758
\end{array}\right]
\end{gathered}
$$

The velocity vectors of GPS benchmark stations MENO, i.e., (6), and MESO, i.e., (7), were transformed to the new reference of frame using Equation (8):

$$
\begin{aligned}
V_{\text {MENO }}= & {\left[\begin{array}{c}
-0.49 \\
0.08 \\
0.55
\end{array}\right] \mathrm{mm} / \text { year } } \\
V_{\text {MESO }}= & {\left[\begin{array}{c}
0.03 \\
0.20 \\
-4.48
\end{array}\right] \mathrm{mm} / \text { year } } \\
& V^{\prime}=R \cdot V
\end{aligned}
$$

The LOS velocity of the two benchmark stations was finally estimated: $V_{\mathrm{LOS}}=-0.16 \mathrm{~mm} / \mathrm{year}$ for MENO and $V_{\mathrm{LOS}}=-3.61 \mathrm{~mm} /$ year for MESO. 
We calibrated the PS and DS datasets by tying the estimated $V_{\mathrm{LOS}}$ at the closest scatterer to the MESO station (i.e., $40 \mathrm{~m}$ away) to the value measured at the GPS station (i.e., $-3.61 \mathrm{~mm} /$ year). As the scatterer originally exhibited a $V_{\text {LOS }}$ of $+0.26 \mathrm{~mm} /$ year, the adjustment meant a $V_{\mathrm{LOS}}$ shift of $-3.87 \mathrm{~mm} /$ year, which was applied to all PS and DS targets.

At MENO station, the calibrated $V_{\text {LOS }}$ from the MT-InSAR analysis equals $-0.19 \mathrm{~mm} / \mathrm{year}$, thus matching extremely well with the $-0.16 \mathrm{~mm} /$ year $V_{L O S}$ measured at the GPS station and providing validating evidence for the MT-InSAR dataset.

To account for the velocity shift due to calibration of the PS and DS targets to MESO station, their time series were also adjusted as follows [61]:

$$
d_{i}\left(t_{n}\right)=d_{i_{\text {old }}}\left(t_{n}\right)-V_{s h} *\left[t_{n}-t_{0}\right]
$$

where $d_{i}\left(t_{n}\right)$ is the adjusted position of target $i$ at time $t_{n}, d_{i_{\text {old }}}\left(t_{n}\right)$ is its original position at time $t_{n}, V_{s h}$ is the $V_{\mathrm{LOS}}$ shift and $t_{0}$ is the first date of the time series.

\subsection{Interpretation of the Observed Ground Deformation}

The maximum $V_{\text {LOS }}$ away from the sensor (i.e., negative values) that is observed after calibrations is $-8.5 \mathrm{~mm} /$ year from the PS dataset and $-18.1 \mathrm{~mm} /$ year from the DS dataset (Figure 6). PS and DS with the strongest movement away from the sensor are located on the eastern flank of the peninsula. Considering the ascending mode-looking geometry and the orientation of the LOS, this could plausibly indicate the occurrence of downslope mass movements. Compared with the topography displayed in Figure $1 \mathrm{~b}$, these movements concentrate on the volcanic ranges and gully erosion landforms above the urban settlements of Methana, Kipseli, Agii Teodori and Agios Georgios. Photo interpretation using Google Earth imagery, however, did not highlight changes of specific landforms for the 2012-2019 period.

The maximum $V_{\text {LOS }}$ towards the sensor (i.e., positive values) from the PS dataset is $+7.5 \mathrm{~mm} /$ year, and that from the DS dataset is $+3.8 \mathrm{~mm} /$ year (Figure 6). Some values above $+3.0 \mathrm{~mm} / \mathrm{year}$ are observed for very few PS and DS scatterers, mainly located on the western flank of Methana peninsula. These scatterers are, however, characterized by a high uncertainty of their deformation rate (i.e., up to $4.0-5.0 \mathrm{~mm}$ /year). Their estimated velocities are therefore not considered as robust as those of other scatterers characterized by higher precision.

The northern portion of Methana town is built onto alluvium, and it seems more stable $\left(V_{\mathrm{LOS}}=-1.8 \mathrm{~mm} /\right.$ year$)$ than the central zone of the town, which is moving away from the satellite at $-2.5 \mathrm{~mm} /$ year (Figure 8a), although both zones show velocities within the range of stability. The central zone is built onto volcanoclasts (Figure $8 \mathrm{c}$ ), and the southern zone onto limestone $(-2.9 \mathrm{~mm} /$ year). The southern zone is moving away from the satellite with relatively low $V_{\text {LOS }}$. Overall, it appears that the majority of the urban area footprint (Figure 8d) is not affected by significant deformation, while somehow, greater rates are found in the suburban zones, as revealed by the DS targets.

The deformation scenario at Vathi and Paleokastro (Figure 9a) shows that there is a slight movement away from the satellite also in this sector of the peninsula. Similar to what was observed for Methana town, PS targets in the region indicates that the urban areas have a mean value of $-0.9 \mathrm{~mm} /$ year, while the DS targets for the suburban and more rural zones show $-3.1 \mathrm{~mm} /$ year.

Annual LOS velocities do not reveal any significant deformation patterns across the sparsely vegetated outcrops at Mavri Petra (Figure 10a), which mostly shows both PS and DS with $V_{\text {LOS }}$ in the range of $\pm 3.0 \mathrm{~mm} /$ year and absence of any clear deformation patterns from the sole observation of the annual LOS velocities. However, evidence of seasonal deformation can be detected in the time series at several locations across the peninsula, including at Mavri Petra (Figure 10b) and at many other sites, for instance at Vathi and Paleokastro (Figure 9b) and at Methana town (Figure 8b). However, in the latter, this happens with less prominent amplitudes. 


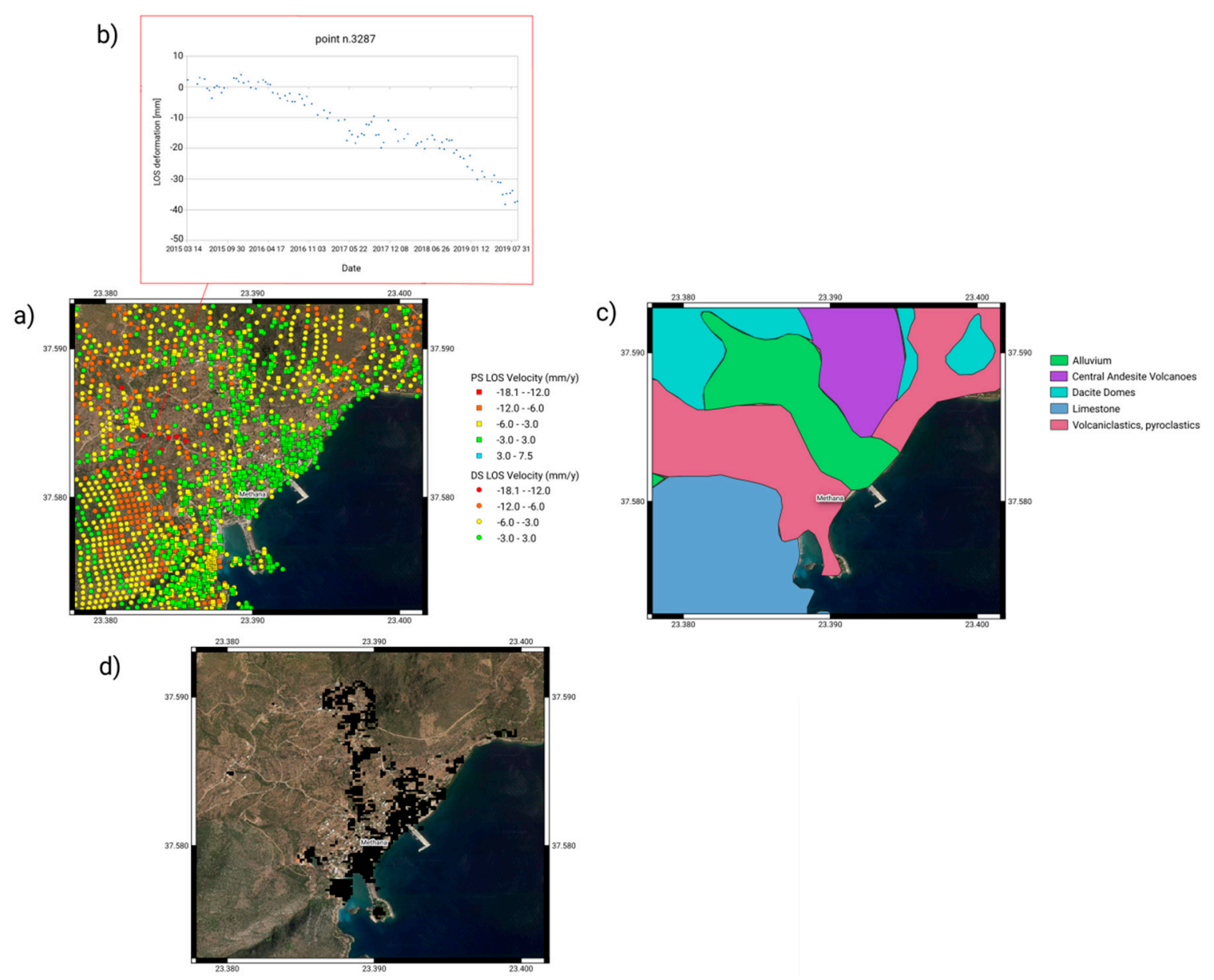

Figure 8. (a) LOS deformation velocity in 2015-2019 from the MT-InSAR analysis, (b) example of time series for a PS located on limestone, (c) geology/lithology and (d) urban footprint of Methana town: (a,c,d) are overlapped onto satellite optical imagery (C) 2020 TerraMetrics, (C) 2020 Google).

The detected seasonal fluctuations at Mavri Petra are significant, both for PS with LOS velocity close to $0 \mathrm{~mm} /$ year and for PS with higher LOS velocity. Those displacements have an amplitude of approximately $5 \mathrm{~mm}$ and periodicity of 1 year (Figure 10b). Similar amplitudes are found at Vathi and Paleokastro (Figure 9b). The peaks of the fluctuations generally occur in the period October-March, i.e., rainfall season [62]. This suggests the presence of a seasonal component in the deformation behaviour that is potentially influenced by rainfall and overlaps onto the long-term, generally linear, trend observed across the peninsula in 2015-2019. In this regard, seasonal signals are commonly observed in surface deformation records in other sites worldwide (e.g., [63]), with annual or even semi-annual periods and different amplitudes from negligible to significant, depending on their driving causes. Future ground deformation investigations in Methana could be focused on identification and removal of such periodical terms via advanced time series processing. This operation would better enhance the long-term deformation behaviour of the observed sites which, in this case, may be partly concealed by these fluctuations.

Higher LOS velocities (e.g., -5.0 to $-10.0 \mathrm{~mm} /$ year) have been observed along steep valleys, mainly on slopes with east orientation (Figure 11a), where visibility of the ascending mode LOS eases the detection of downslope mass movements. The observed displacement could therefore be related to extremely to very slow mass movements and slope instability affecting rugged terrain and volcanic landforms that are recognized as prone to landslides and rock-falls [18]. Some seasonal fluctuations are also detected in the time series (Figure 11b). 


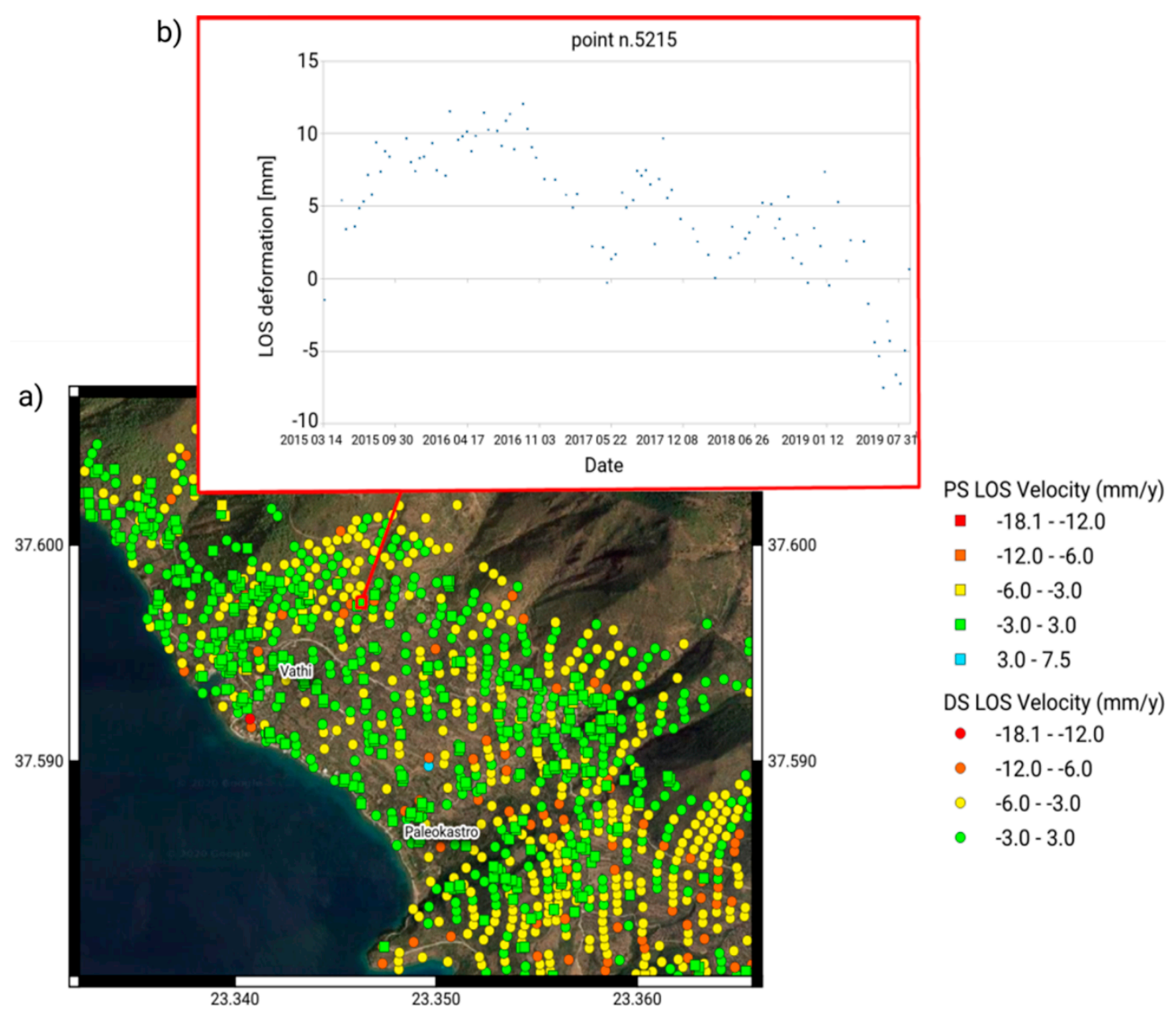

Figure 9. (a) LOS deformation velocity over Vathi and Paleokastro in 2015-2019 from the MT-InSAR analysis overlapped onto satellite optical imagery (C) 2020 TerraMetrics, (C) 2020 Google) and (b) example of time series for a PS located near Vathi town.

When the evidence from the MT-InSAR investigation is integrated with the outcomes of the GNSS data analysis (see Section 4.1), it can be suggested that the ground motions that are observed from 2015 to 2019 are compatible with the anticipated "low" volcanic activity of Methana. This comes out very

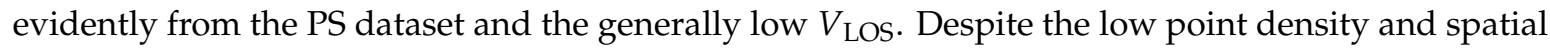
coverage of the volcanic edifice, the overall spatial distribution of the PS deformation values does not reveal a deformation field that could be reliably attributed to a typical volcanic inflation/deflation dynamic of the whole Methana, as found in the literature for other active volcanic areas. On the other hand, the DS dataset may suggest the presence of more widespread deformation patterns along the eastern flank. However, there are only few cases where the observed motions associate with specific landforms (e.g., narrow valleys, erosion gullies and superficial slides). In this regard, the photo interpretation of the slopes through Google Earth optical imagery did not highlight specific circumstances worth further investigation. 


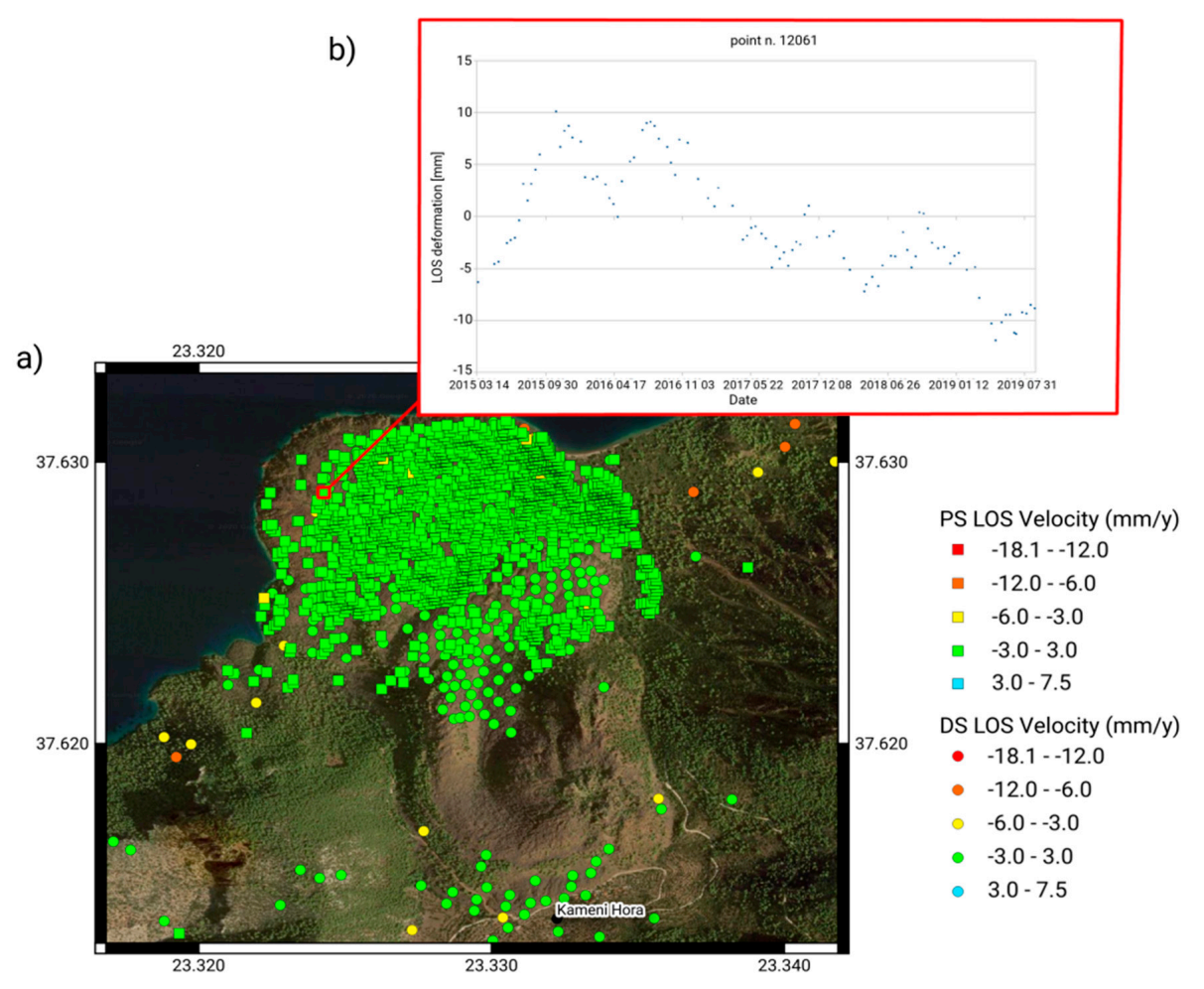

Figure 10. (a) LOS deformation velocity over Mavri Petra in 2015-2019 from the MT-InSAR analysis overlapped onto satellite optical imagery (C) 2020 TerraMetrics, (C) 2020 Google) and (b) example of time series for a PS located in the NW portion of Mavri Petra.

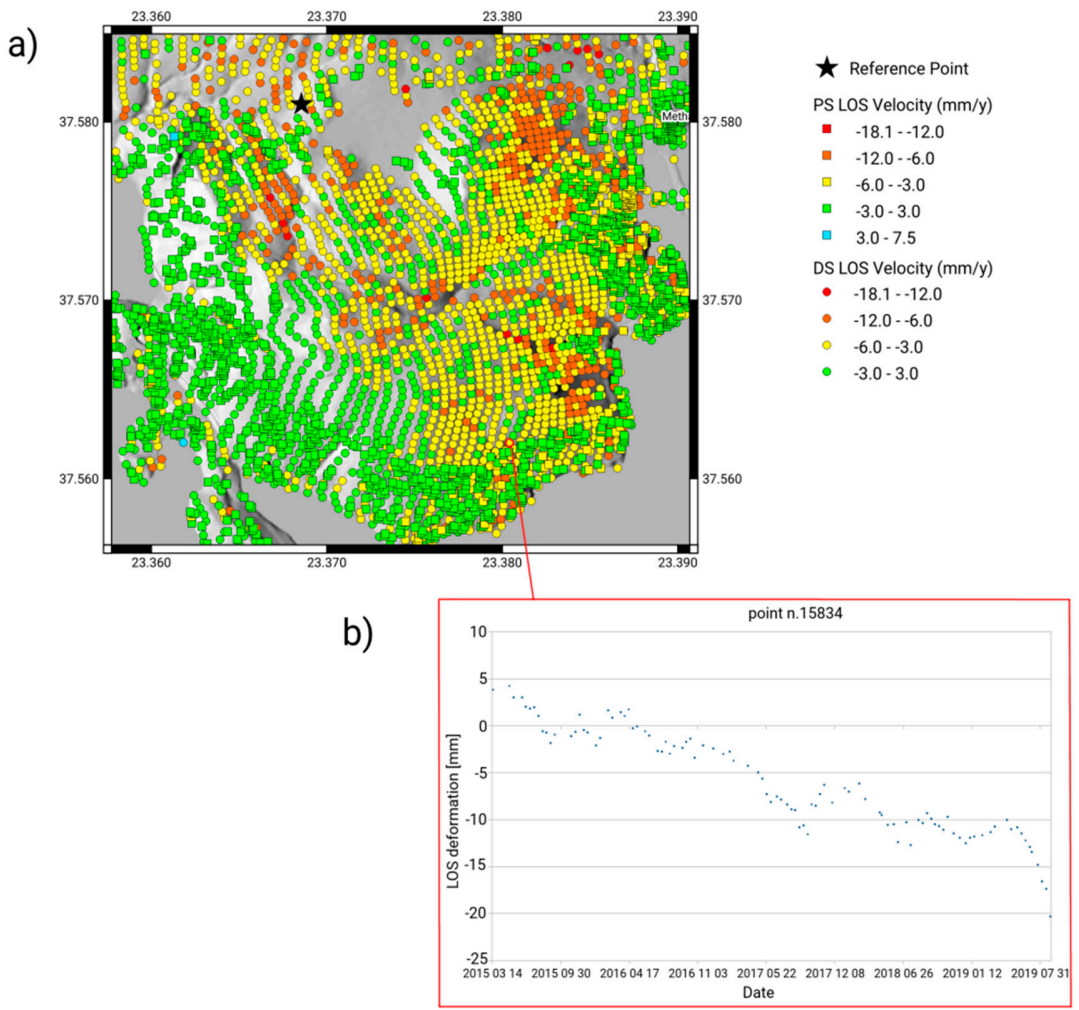

Figure 11. (a) LOS deformation velocity over the southern portion of Methana peninsula in 2015-2019 from the MT-InSAR analysis overlapped onto shaded relief of the 5.5-m digital surface model by the Hellenic Mapping and Cadastral Organisation and (b) example of time series for a DS located in the SE part of Methana peninsula. 
Due to the lack of strong seismic events $(\mathrm{Mw}>4)$ or intense seismicity in the area of Methana peninsula (see Section 4.2), the observed ground deformation could not be associated with the recorded seismicity. There are active seismic zones in the vicinity of the peninsula; however, neither the location, the depth nor the magnitude of these events could be directly associated with the observed motions. Even if a seismic contribution to triggering superficial mass movements was present, this would be plausibly limited to nearby seismic swarms. However, there is no hard evidence from ground observations to support further such a hypothesis.

Accounting for the geothermal activity and warm springs at various locations in Methana, the only situation where motions were found close to a thermal spring is in the immediate vicinity of the open-air thermal baths of the Thermal Spa in the southern part of Methana town (see Figure 8a). However, the LOS deformation rate values found in the PS dataset most likely associate with rock-fall accumulation overlooking the road (Figure 12), while those in the DS dataset cannot be easily separated from the wider deformation pattern extending across the above topography (see Figure 11). The seasonality observed in the MT-InSAR time series in this area as well as at many other locations of the peninsula appear to be more plausibly due to soil moisture and groundwater level oscillations, partly controlled by precipitation, as discussed above. On the other hand, another process that could explain such seasonality could be linked with fluctuations in the geothermal reservoir located in the centre of Methana at a depth of approximately $2 \mathrm{~km}$ [64], though more investigation would be needed to verify the potential occurrence of such a process.
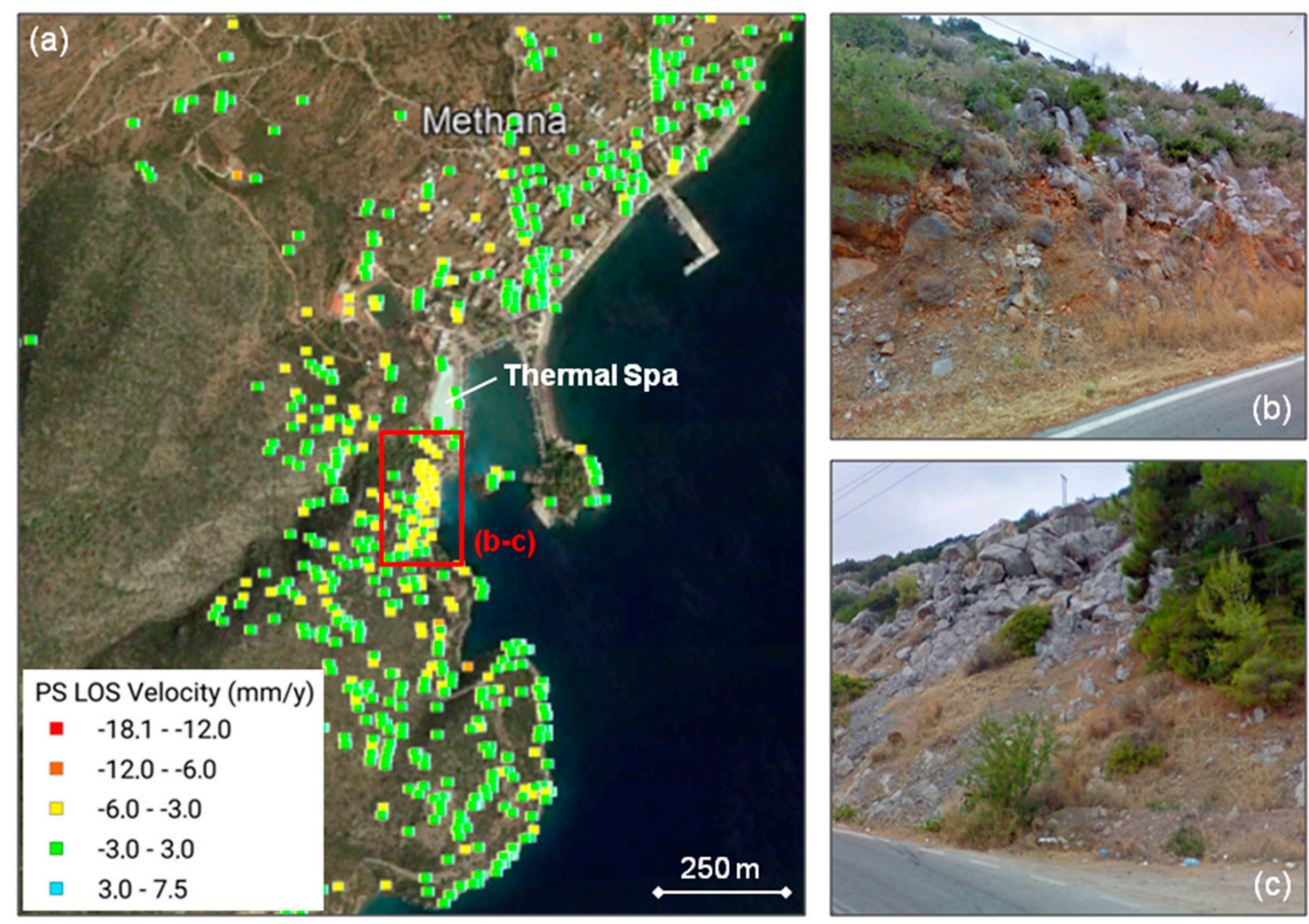

Figure 12. (a) LOS deformation velocity of the PS over Methana town in 2015-2019 from the MT-InSAR analysis overlapped onto satellite optical imagery (C) 2020 TerraMetrics, (C) 2020 Google) and (b,c) ground-truth photographs of rock-fall accumulation along the Methana-Taktikopolis road (C 2020 Google). 


\section{Conclusions}

In the context of the abundant literature of satellite InSAR studies on the south Aegean volcanic arc and the published geological and geochemical research on Methana, the present study is the first that undertakes a multi-temporal InSAR analysis of the most recent ground motions in the peninsula in the period 2015-2019 and attempts to find correlations with local GPS benchmark, cGNSS and regional seismicity data collected since 2006. Methana is located in the seismically active neotectonic basin constituting the Saronic Gulf area, and recent efforts have been made by Greek institutions to specifically monitor the peninsula, among which is the nomination of the Permanent Scientific Committee "Greek Volcano Arc Monitoring" by the administrative board of the Earthquake Planning and Protection Organization (EPPO) in June 2020. In this context, this study is timely in starting to put together initial geodetic and satellite datasets to create a virtual monitoring network that, in the future, could be developed into a proper volcano observatory system.

Based on the integrated data analysis, the general conclusion of this research is that the ground motions observed in the Sentinel-1 MT-InSAR ascending mode data are compatible with the anticipated "low" volcanic activity of Methana. Although the volcano does not show clear signs of activity in recent years, it is a hotspot of potential concern given that it is adjacent to very high-density population areas, including Athens and the surrounding major towns. The interpreted low level of activity is clearly the initial baseline above which further investigations need to be conducted and will need to be verified once the whole archive of SAR datasets dating back to the early 1990s is analysed (e.g., ERS-1/2 and ENVISAT) and the ascending geometry of Sentinel-1 made available for this research is complemented with same InSAR analysis of the matching descending dataset acquired over the peninsula since 2014. It is evident that the use of one SAR geometry only limits the extent to which the observed LOS ground motions can be interpreted. Therefore, future research may include processing of SAR data (even at higher spatial resolution) from both ascending and descending geometries and reconstruction of the 3D deformation field as well as longer time series of geodetic data to improve our understanding of the long-term deformation behaviour of the peninsula.

Author Contributions: Conceptualization, F.C., D.T. and I.P.; methodology, T.G., F.C., D.T. and V.S.; software, T.G., V.S. and K.P.; validation, T.G., V.S. and K.P.; formal analysis, T.G., F.C., D.T., V.S. and K.P.; investigation, T.G., F.C., D.T., V.S. and K.P.; resources, I.P.; data curation, T.G., V.S. and K.P.; writing-original draft preparation, T.G., F.C., D.T., V.S. and K.P.; writing-review and editing, I.P.; supervision, F.C. and I.P. All authors have read and agreed to the published version of the manuscript.

Funding: Remeasurement of the GPS benchmarks MESO and MENO was financed by "HELPOS-Hellenic Plate Observing System" (MIS 5002697), which is implemented under the action "Reinforcement of the Research and Innovation Infrastructure", funded by the Operational Programme "Competitiveness, Entrepreneurship and Innovation" (NSRF 2014-2020) and co-financed by Greece and the European Union (European Regional Development Fund).

Acknowledgments: Copernicus Sentinel-1 SAR data were accessed through the Sentinel Hub platform (https://scihub.copernicus.eu/) and processed using the GAMMA SAR and Interferometry software licensed to Harokopio University of Athens and ESA's SNAP software. GNSS data were provided by the National Technical University of Athens (NTUA) for METH station, by HxGN SmartNet for LYGO station, and by the Institute of Geodynamics of the National Observatory of Athens (NOA) for MTNA and 010A stations. Seismic data were provided by the Department of Geophysics and Geothermy, National and Kapodistrian University of Athens (NKUA) (http://dggsl.geol.uoa.gr/en_index.html). High-resolution DSM was provided by the Hellenic Mapping and Cadastral Organisation. Some of the figures were created with the Generic Mapping Tool (GMT) software [65].

Conflicts of Interest: The authors declare no conflict of interest.

\section{Appendix A}

Daily solutions for the continuous GNSS stations in Lygourio (LYGO) and in the western part of Methana (MTNA) are provided in Figures A1 and A2, respectively. 


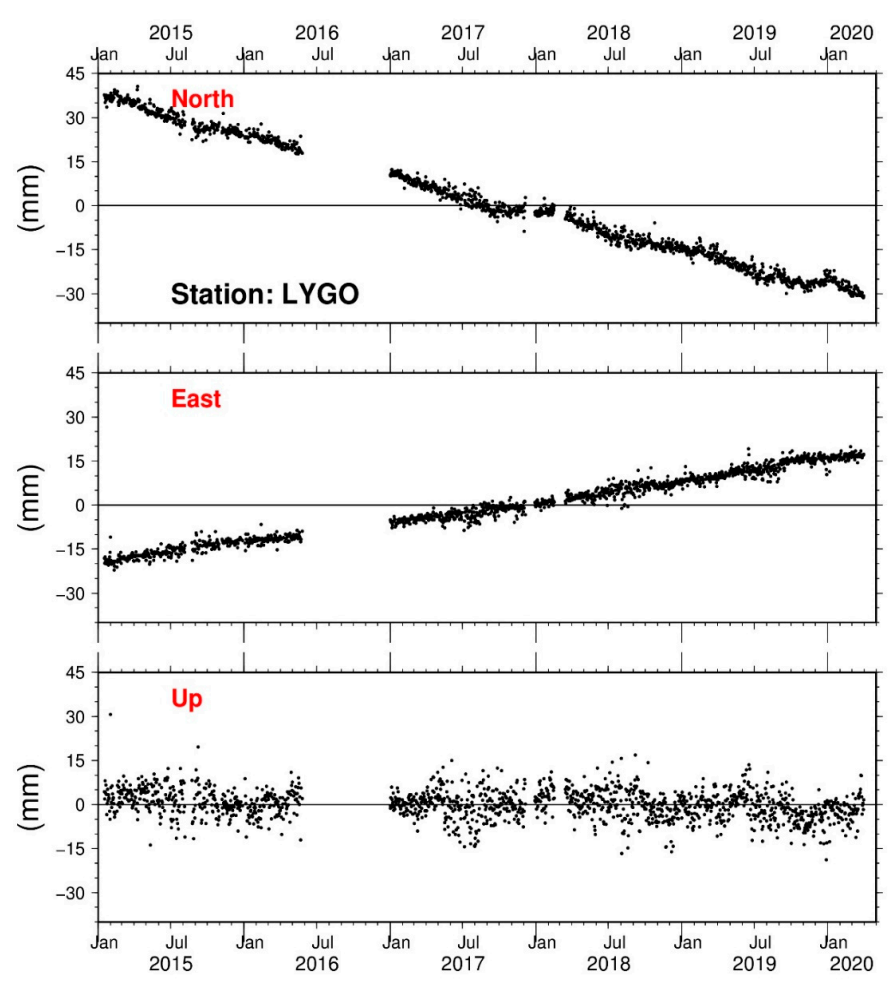

GWII 2020 Sep 11 11:43:15] NKUA - Laboratory of Geophysice

Figure A1. Time series for the three components of the daily solutions, spanning from January 2015 to March 2020, for the continuous GNSS station in the Lygourio (LYGO) area, west of Methana peninsula.
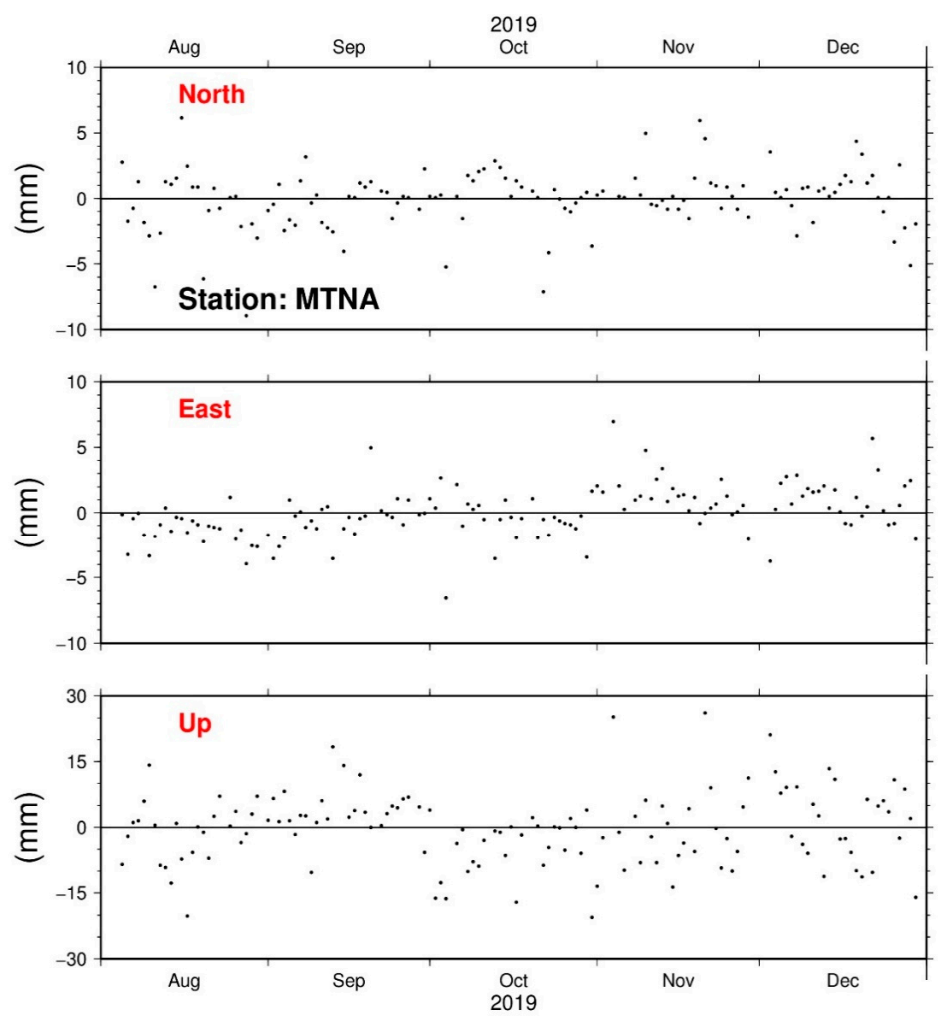

GMS 2020 Sep 11 11:49:14 NKUA - Laboratory of Geophysics

Figure A2. Time series for the three components of the daily solutions, spanning from August to December 2020, for the continuous GNSS station MTNA, located in the western part of Methana peninsula. 


\section{References}

1. Zouros, N. Assessment, protection, and promotion of geomorphological and geological sites in the Aegean area, Greece. Géomorphosites Définition Évaluation Cartogr. 2005, 11, 227-234. [CrossRef]

2. Kyriakopoulos, K.G. Volcanoes "Monuments of Nature". In Natural Heritage from East to West: Case Studies from 6 EU Countries; Springer: Berlin/Heidelberg, Germany, 2010; pp. 59-70. ISBN 9783642015762.

3. D'Alessandro, W.; Brusca, L.; Kyriakopoulos, K.; Michas, G.; Papadakis, G. Methana, the westernmost active volcanic system of the south Aegean arc (Greece): Insight from fluids geochemistry. J. Volcanol. Geotherm. Res. 2008, 178, 818-828. [CrossRef]

4. Vougioukalakis, G.E.; Fytikas, M. Volcanic hazards in the Aegean area, relative risk evaluation, monitoring and present state of the active volcanic centers. Dev. Volcanol. 2005, 7, 161-183. [CrossRef]

5. Makris, J.; Papoulia, J.; Drakatos, G. Tectonic deformation and microseismicity of the Saronikos Gulf, Greece. Bull. Seismol. Soc. Am. 2004, 94, 920-929. [CrossRef]

6. Scientists Decide to Increase Monitoring of Methana Volcano Near Athens|Neos Kosmos. Available online: https: //neoskosmos.com/en/130406/scientists-decide-increase-monitoring-of-methana-volcano-near-athens/ (accessed on 14 August 2020).

7. NOANET, Station Mtna. Available online: http://geodesy.gein.noa.gr:8000/nginfo/mtna/ (accessed on 14 August 2020).

8. Parcharidis, I.; Lagios, E. Deformation in Nisyros volcano (Greece) using differential radar interferometry. Bull. Geol. Soc. Greece 2001, 34, 1587. [CrossRef]

9. Ganas, A.; Lagios, E.; Dietrich, V.J.; Vassilopoulou, S.; Hurni, L.; Stavrakakis, G. Interferometric Mapping of Ground Deformation in Nissyros Volcano, Aegean Sea, during 1995-1996. In Proceedings of the 6th Pan-Hellenic Geographical Congress, Thessaloniki, Greece, 3-6 October 2002; Volume II, pp. 135-141.

10. Sachpazi, M.; Kontoes, C.; Voulgaris, N.; Laigle, M.; Vougioukalakis, G.; Sikioti, O.; Stavrakakis, G.; Baskoutas, J.; Kalogeras, J.; Lepine, J.C. Seismological and SAR signature of unrest at Nisyros caldera, Greece. J. Volcanol. Geotherm. Res. 2002, 116, 19-33. [CrossRef]

11. Parcharidis, I.; Sakkas, V.A.; Ganas, A.; Katopodi, A. A production of Digital Elevation Model (DEM) by means of SAR tandem images in a volcanic landscape and its quality assessment. In Proceedings of the 6th Pan-Hellenic Geographical Conference of the Hellenic Geographical Society, Thessaloniki, Greece, 3-6 October 2002; Volume 2, pp. 201-207.

12. Sykioti, O.; Kontoes, C.C.; Elias, P.; Briole, P.; Sachpazi, M.; Paradissis, D.; Kotsis, I. Ground deformation at Nisyros volcano (Greece) detected by ERS-2 SAR differential interferometry. Int. J. Remote Sens. 2003, 24, 183-188. [CrossRef]

13. Parcharidis, I.; Lagios, E.; Sakkas, V. Differential interferometry as a tool of an early warning system in reducing the volcano risk: The case of Nisyros Volcano. In Proceedings of the of the 10th Congress of the Geological Society of Greece, Athens, Greece, 15-17 April 2004; Extended Abstracts. National Documentation Centre: Athina, Greece, 2004; pp. 913-918.

14. Lagios, E.; Sakkas, V.; Parcharidis, I.; Dietrich, V. Ground deformation of Nisyros Volcano (Greece) for the period 1995-2002: Results from DInSAR and DGPS observations. Bull. Volcanol. 2005, 68, 201-214. [CrossRef]

15. Mouratidis, A.F.; Tsakiri-Strati, M.; Astaras, T. SAR Interferometry for Geoscience applications in Greece. In The Apple of Knowledge: Volume in Honor of Prof. D. Arabelos; Kaltsikis, C., Kontadakis, M.E., Spatalas, S., Tziavos, I.N., Tokmakidis, K., Eds.; Publication of the School of Rural \& Surveying Engineering: Thessaloniki, Greece, 2010; pp. 340-350.

16. Foumelis, M.; Trasatti, E.; Papageorgiou, E.; Stramondo, S.; Parcharidis, I. Monitoring Santorini volcano (Greece) breathing from space. Geophys. J. Int. 2013, 193, 161-170. [CrossRef]

17. Papageorgiou, E.; Foumelis, M.; Trasatti, E.; Ventura, G.; Raucoules, D.; Mouratidis, A. Multi-sensor SAR geodetic imaging and modelling of santorini volcano post-unrest response. Remote Sens. 2019, 11, 259. [CrossRef]

18. Antoniou, V.; Nomikou, P.; Bardouli, P.; Lampridou, D.; Ioannou, T.; Kalisperakis, I.; Stentoumis, C.; Whitworth, M.; Krokos, M.; Ragia, L. An Interactive Story Map for the Methana Volcanic Peninsula. In Proceedings of the 4th International Conference on Geographical Information Systems Theory, Applications and Management (GISTAM 2018), Madeira, Portugal, 17-19 March 2018; Scitepress: Setúbal, Portugal, 2018; pp. 68-78. 
19. Nomikou, P.; Papanikolaou, D.; Alexandri, M.; Sakellariou, D.; Rousakis, G. Submarine volcanoes along the aegean volcanic arc. Tectonophysics 2013, 597-598, 123-146. [CrossRef]

20. Francalanci, L.; Vougioukalakis, G.E.; Perini, G.; Manetti, P. A West-East Traverse along the magmatism of the south Aegean volcanic arc in the light of volcanological, chemical and isotope data. Dev. Volcanol. 2005, 7,65-111. [CrossRef]

21. Pe-Piper, G.; Piper, D.J.W. The effect of changing regional tectonics on an arc volcano: Methana, Greece. J. Volcanol. Geotherm. Res. 2013, 260, 146-163. [CrossRef]

22. Popa, R.G.; Dietrich, V.J.; Bachmann, O. Effusive-explosive transitions of water-undersaturated magmas. The case study of Methana Volcano, South Aegean Arc. J. Volcanol. Geotherm. Res. 2020, 399, 106884. [CrossRef]

23. Dotsika, E.; Poutoukis, D.; Raco, B. Fluid geochemistry of the Methana Peninsula and Loutraki geothermal area, Greece. J. Geochem. Explor. 2010, 104, 97-104. [CrossRef]

24. Pe-Piper, G.; Piper, D.J.W. The Igneous Rocks of Greece: The Anatomy of an Orogen; Gebr. Borntraeger: Stuttgart, Germany, 2002; ISBN 9783443110307.

25. Papanikolaou, D.; Chronis, G.; Lykousis, V.; Pavlakis, P. Submarine Neotectonic Map of Saronikos Gulf; Earthquake, Planning and Protection Organization of Greece: Thessaloniki, Greece, 1989.

26. Pavlakis, P.; Lykoussis, V.; Papanikolaou, D.; Chronis, G. Discovery of a new submarine volcano in the western Saronic Gulf: The Paphsanias Volcano. Bull. Hell. Geol. Soc. Greece 1990, XXIV, 59-70.

27. Fytikas, M.; Innocenti, F.; Kolios, N. The Plio-Quaternary volcanism of Saronikos area (western part of the active part of the Aegean volcanic arc). Ann. Géologiques Pays Helléniques 1988, 33, 23-45.

28. Armijo, R.; Meyer, B.; King, G.C.P.; Rigo, A.; Papanastassiou, D. Quaternary evolution of the Corinth Rift and its implications for the Late Cenozoic evolution of the Aegean. Geophys. J. Int. 1996, 126, 11-53. [CrossRef]

29. Makropoulos, K.; Kaviris, G.; Kouskouna, V. An updated and extended earthquake catalogue for Greece and adjacent areas since 1900. Nat. Hazards Earth Syst. Sci. 2012, 12, 1425-1430. [CrossRef]

30. Dietrich, V.J.; Mercolli, I.; Oberhänsli, R. Dazite, High-Alumina-Basalte und Andesite als Produkte amphiboldominierter Differentation (Aegina und Methan, Ägäischer Inselbogen). Schweiz. Mineral. Petrogr. Mitt. 1988, 68, 21-39.

31. Gaitanakis, P.; Dietrich, A.D. Geological Map of Methana Peninsula, 1:25 000; Swiss Federal Institute of Technology: Zurich, Switzerland, 1995.

32. Pe-Piper, G.; Piper, D.J.W. The South Aegean active volcanic arc: Relationships between magmatism and tectonics. Dev. Volcanol. 2005, 7, 113-133. [CrossRef]

33. Volti, T.K. Magnetotelluric measurements on the Methana Peninsula (Greece): Modelling and interpretation. Tectonophysics 1999, 301, 111-132. [CrossRef]

34. Curlander, J.C.; Mcdonough, R.N. Synthetic Aperture Radar: Systems and Signal Processing; Wiley: Hoboken, NJ, USA, 1991; ISBN 978-0-471-85770-9.

35. Torres, R.; Snoeij, P.; Geudtner, D.; Bibby, D.; Davidson, M.; Attema, E.; Potin, P.; Rommen, B.Ö.; Floury, N.; Brown, M.; et al. GMES Sentinel-1 mission. Remote Sens. Environ. 2012, 120, 9-24. [CrossRef]

36. Berger, M.; Moreno, J.; Johannessen, J.A.; Levelt, P.F.; Hanssen, R.F. ESA's sentinel missions in support of Earth system science. Remote Sens. Environ. 2012, 120, 84-90. [CrossRef]

37. Bamler, R.; Hartl, P. Synthetic aperture radar interferometry. Inverse Probl. 1998, 14, R1. [CrossRef]

38. Rosen, P.A.; Hensley, S.; Joughin, I.R.; Li, F.K.; Madsen, S.N.; Rodriguez, E.; Goldstein, R.M. Synthetic aperture radar interferometry. Proc. IEEE 2000, 88, 333-380. [CrossRef]

39. Crosetto, M.; Monserrat, O.; Cuevas-González, M.; Devanthéry, N.; Crippa, B. Persistent Scatterer Interferometry: A review. ISPRS J. Photogramm. Remote Sens. 2016, 115, 78-89. [CrossRef]

40. Amelung, F.; Galloway, D.L.; Bell, J.W.; Zebker, H.A.; Laczniak, R.J. Sensing the ups and downs of Las Vegas: InSAR reveals structural control of land subsidence and aquifer-system deformation. Geology 1999, 27, 483-486. [CrossRef]

41. Dixon, T.H.; Amelung, F.; Ferretti, A.; Novali, F.; Rocca, F.; Dokka, R.; Sella, G.; Kim, S.W.; Wdowinski, S.; Whitman, D. Space geodesy: Subsidence and flooding in New Orleans. Nature 2006, 441, 587-588. [CrossRef] 
42. Herrera, G.; Davalillo, J.C.; Mulas, J.; Cooksley, G.; Monserrat, O.; Pancioli, V. Mapping and monitoring geomorphological processes in mountainous areas using PSI data: Central Pyrenees case study. Nat. Hazards Earth Syst. Sci. 2009, 9, 1587-1598. [CrossRef]

43. Cigna, F.; Tapete, D.; Garduño-Monroy, V.H.; Muñiz-Jauregui, J.A.; García-Hernández, O.H.; Jiménez-Haro, A. Wide-area InSAR survey of surface deformation in urban areas and geothermal fields in the eastern Trans-Mexican Volcanic Belt, Mexico. Remote Sens. 2019, 11, 2341. [CrossRef]

44. Spaans, K.; Hooper, A. InSAR processing for volcano monitoring and other near-real time applications. J. Geophys. Res. Solid Earth 2016, 121, 2947-2960. [CrossRef]

45. Cigna, F.; Bianchini, S.; Casagli, N. How to assess landslide activity and intensity with Persistent Scatterer Interferometry (PSI): The PSI-based matrix approach. Landslides 2013, 10, 267-283. [CrossRef]

46. Ferretti, A.; Prati, C.; Rocca, F. Nonlinear subsidence rate estimation using permanent scatterers in differential SAR interferometry. IEEE Trans. Geosci. Remote Sens. 2000, 38, 2202-2212. [CrossRef]

47. Ferretti, A.; Prati, C.; Rocca, F. Permanent scatterers in SAR interferometry. IEEE Trans. Geosci. Remote Sens. 2001, 39, 8-20. [CrossRef]

48. Berardino, P.; Fornaro, G.; Lanari, R.; Sansosti, E. A new algorithm for surface deformation monitoring based on small baseline differential SAR interferograms. IEEE Trans. Geosci. Remote Sens. 2002, 40, 2375-2383. [CrossRef]

49. Ferretti, A.; Fumagalli, A.; Novali, F.; Prati, C.; Rocca, F.; Rucci, A. A new algorithm for processing interferometric data-stacks: SqueeSAR. IEEE Trans. Geosci. Remote Sens. 2011, 49, 3460-3470. [CrossRef]

50. Shamshiri, R.; Nahavandchi, H.; Motagh, M.; Hooper, A. Efficient Ground Surface Displacement Monitoring Using Sentinel-1 Data: Integrating Distributed Scatterers (DS) Identified Using Two-Sample t-Test with Persistent Scatterers (PS). Remote Sens. 2018, 10, 794. [CrossRef]

51. Cigna, F.; Sowter, A. The relationship between intermittent coherence and precision of ISBAS InSAR ground motion velocities: ERS-1/2 case studies in the UK. Remote Sens. Environ. 2017, 202, 177-198. [CrossRef]

52. Werner, C.; Wegmüller, U.; Strozzi, T.; Wiesmann, A. Interferometric Point Target Analysis for Deformation Mapping. In Proceedings of the International Geoscience and Remote Sensing Symposium (IGARSS), Toulouse, France, 21-25 July 2003; Volume 7, pp. 4362-4364.

53. Farr, T.G.; Rosen, P.A.; Caro, E.; Crippen, R.; Duren, R.; Hensley, S.; Kobrick, M.; Paller, M.; Rodriguez, E.; Roth, L.; et al. The shuttle radar topography mission. Rev. Geophys. 2007, 45, RG2004. [CrossRef]

54. Papageorgiou, E. Crustal movements along the NW Hellenic volcanic arc from DGPS measurements. Bull. Geol. Soc. Greece 2010, 43, 331. [CrossRef]

55. Chousianitis, K.; Ganas, A.; Gianniou, M. Kinematic interpretation of present-day crustal deformation in central Greece from continuous GPS measurements. J. Geodyn. 2013, 71, 1-13. [CrossRef]

56. Dach, R.; Lutz, S.; Walser, P.; Fridez, P. Bernese GNSS Software Version 5.2; User Manual; Astronomical Institute, University of Bern, Bern Open Publishing: Bern, Switzerland, 2015.

57. Ray, R.D.; Ponte, R.M. Barometric tides from ECMWF operational analyses. Ann. Geophys. 2003, 21, 1897-1910. [CrossRef]

58. Klein, F.W. User's Guide to HYPOINVERSE, a Program for VAX Computers to Solve for Earthquake Locations and Magnitudes; U.S. Geological Survey: Menlo Park, CA, USA, 1989.

59. Karakonstantis, A.; Papadimitriou, P.; Millas, C.; Spingos, I.; Fountoulakis, I.; Kaviris, G. Tomographic imaging of the NW edge of the Hellenic volcanic arc. J. Seismol. 2019, 23, 995-1016. [CrossRef]

60. Papanikolaou, D.; Lykousis, V.; Chronis, G.; Pavlakis, P. A comparative study of neotectonic basins across the Hellenic arc: The Messiniakos, Argolikos, Saronikos and Southern Evoikos Gulfs. Basin Res. 1988, 1, 167-176. [CrossRef]

61. Bateson, L.; Cuevas, M.; Crosetto, M.; Cigna, F.; Schijf, M.; Evans, H. PANGEO: Enabling Access to Geological Information in Support of GMES: Deliverable 3.5 Production Manual. Version 1; European Commission: Brussels, Belgium, 2012.

62. Climate-Data.org Methana Climate: Average Temperature, Weather by Month, Methana Water TemperatureClimate-Data.org. Available online: https://en.climate-data.org/europe/greece/methana/methana-27566/ (accessed on 18 August 2020). 
63. Berti, M.; Corsini, A.; Franceschini, S.; Iannacone, J.P. Automated classification of Persistent Scatterers Interferometry time series. Nat. Hazards Earth Syst. Sci. 2013, 13, 1945-1958. [CrossRef]

64. Tzanis, A.; Efstathiou, A.; Chailas, S.; Lagios, E.; Stamatakis, M. The Methana Volcano-Geothermal Resource, Greece, and its relationship to regional tectonics. J. Volcanol. Geotherm. Res. 2020, 404, 107035. [CrossRef]

65. Wessel, P.; Smith, W.H.F. New, improved version of Generic Mapping Tools released. EOS Trans AGU 1998, 79, 579. [CrossRef]

(C) 2020 by the authors. Licensee MDPI, Basel, Switzerland. This article is an open access article distributed under the terms and conditions of the Creative Commons Attribution (CC BY) license (http://creativecommons.org/licenses/by/4.0/). 